\title{
КАРАВАН-САРАИ: ГЕНЕЗИС, РЕГИОНАЛЬНЫЕ ОСОБЕННОСТИ, КЛАССИФИКАЦИЯ
}

\author{
(C) 2019 г. Э.Д. Зиливинская
}

С развитием торговли на караванных путях появляются постоялые дворы, причем самые ранние известны уже во II тыс. до н.э. После арабских завоеваний на Востоке складывается достаточно стандартный и хорошо узнаваемый тип постоялого двора, получивший название «караван-сарай» или «хан». В Средней Азии и Иране в основе плана караван-сараев лежит обширный двор, окруженный мощными стенами, к которым изнутри пристроены различные помещения. В Армении был выработан оригинальный тип закрытого зального караван-сарая. Наиболее распространенный в Малой Азии тип караван-сараев представляет собой синтез дворовых и зальных зданий. Несмотря на то, что существует достаточно много обобщающих работ, в которых собраны и проанализированы караван-сараи различных стран Востока, до сих пор не создана классификация этой очень важной категории зданий. Предлагаемая типология основывается на планиметрии построек. В предлагаемой классификации используются следующие признаки: наличие или отсутствие открытого двора, количество дворов, форма плана, количество входов, застройка двора, расположение помещений, наличие колоннады. Предложенная классификация достаточно универсальна и отражает большую часть элементов, из которых строится план здания. Кроме того, она позволяет изобразить планировку зданий в виде краткого кода.

Ключевые слова: археология, Средняя Азия, Армения, Малая Азия, Иран, Великий Шелковый путь, средневековье, торговля, караван-сараи, генезис, классификация

Торговля являлась важнейшей составляющей жизни человеческого общества с древнейших времен. Внутренняя, а затем и внешняя торговля становятся существенным фактором исторического развития стран, относящихся к древнейшим цивилизационным центрам, таким как Китай, Индия, Древний Египет, Месопотамия, Греция. Осуществление торговых связей требовало длительных экспедиций в отдаленные районы страны и за ее рубежи. Постепен- но складываются постоянные торговые маршруты, на которых строятся станции или постоялые дворы для отдыха усталых путников и торговых караванов. В Индии, в МохенджоДаро, городе ремесленников и торговцев III-II тыс. до н. э., раскопками обнаружены общественные здания, такие как харчевни, бани, склады, крытые рынки и постоялые дворы [ВИА, 1970, с. 385-386]. На Крите, напротив Кносского дворца, исследовано здание, также считающееся 
гостиницей XV в. до н. э. В состав помещений входили парадный павильон, бассейн для омовения ног, ванная и помещения для ночлега [ВИА, 1970 , с. 182].

Во II в. до н. э. на Востоке сложился Великий Шелковый путь. Он был оборудован колодцами и постоялыми дворами. К парфянскому времени относится городской постоялый двор в Дура-Европос - торговоперевалочном пункте на пути караванов. Планировка его напоминает более поздние караван-сараи, так как в основе плана лежит большой двор, по периметру которого находятся различные помещения [ВИА, 1970, с. 318 , рис. 29].

В средние века в Центральной Азии до прихода арабов на торговых путях существовали постоялые дворы как необходимый элемент международной торговли. В Иране в сасанидское время строились «торговые крепости», служившие для обороны, но приспособленные для приема и содержания купеческих караванов [Хмельницкий, 1992, с. 179]. В Средней Азии в доисламский период таких учреждений известно не много. В Ташкентском оазисе исследовано каменное здание с большим внутренним двором, которое предположительно считается каравансараем середины I тыс. н. э. [Буряков, 1978, с. 56-57]. Есть данные, что в VII-VIII вв. в Согде существовали постоялые дворы, причем, судя по письменным источникам, владельцем двух из них был согдийский правитель Дивашчич [Смирнова, 1970, c. 138-139].

Только после арабских завоеваний на Востоке складывается достаточно стандартный и хорошо узнаваемый тип постоялого двора, предназначенного для купеческих кара- ванов. В арабских странах такие постройки назывались караван-сарай, то есть дворец для караванов, а в областях, где преобладали тюркские языки, к ним применялось название хан. В первые века Хиджры, во время арабских завоеваний, на Востоке возводились крепости для борцов за веру газиев, которые назывались puбаты. Впоследствии, в более спокойные времена, они превращаются в придорожные гостиницы, часто сохраняя название рибат или рабат [Немцева, 1983, с. 139-141; Хмельницкий, 1992, с. 180; Hillenbrand, 1994, p. 331-332]. В XI-XII вв. в постоялые дворы были перестроены и некоторые замки (кешки) [Пугаченкова, 1958a, с. 166-167].

Караван-сараи возводились вдоль караванных путей на расстояниях, которые равнялись дневному переходу (около 35-45 км). Эти постройки сохранили вид хорошо укрепленных крепостей с мощными стенами и единственными воротами. Углы могут быть фланкированы круглыми башнями, а к стенам пристроены полубашни. Прямоугольник стен окружает обширный двор, внутри которого вдоль стен тянутся галереи помещений различного назначения: стойла для вьючных животных, складские помещения для товаров, комнаты для гостей. В хорошо благоустроенных караван-сараях были сделаны банные помещения и почти всегда находилась мечеть. Некоторые крупные караван-сараи, такие как, например, Рабат-и Малик (особенно во втором периоде), действительно напоминали загородные дворцы и, вполне возможно, в составе помещений имели покои, в которых останавливались правители и другие важные гости во время путешествий. Для защиты караванов от разбойников в 
придорожных гостиницах мог быть небольшой военный гарнизон. Рядом обязательно находились источники воды - колодцы или сардоба.

Караван-сараи играли важную роль не только для торговли, но и для всей системы коммуникаций в средние века. Часто с караванами купцов пускались в странствие дипломаты, паломники, просто путешественники.

Строительство караван-сараев вдоль крупных торговых путей осуществлялось государственной властью. Известно, что Омейадский халиф Омар II (717-720) вменил в число главных обязанностей для своих наместников постройку подворий (ханов) [Бартольд, 1963, с. 245]. Источники отмечают строительство ханов в пустынных местностях омейадским наместником Хорасана Асадом ибн Абдаллахом в VIII в. [Бартольд, 1963 , с. 250]. Особого размаха возведение придорожных гостиниц достигло в X-XII вв. По сведениям Ал Истахри и Ибн Хаукаля в Мавераннахре в X в. было более 10 тыс. постоялых дворов. В них предоставляли корм животным, еду и постель людям. Кроме придорожных гостиниц были караван-сараи при въезде в города и внутри городских стен. Городские караван-сараи были не только гостиницами, но в них также могли находиться мастерские ремесленников и лавки торговцев. Средневековые городские караван-сараи изучены слабо, так как они почти не сохранились, зато придорожные постоялые дворы известны во множестве во всех восточных странах.

В Средней Азии и Иране в основе плана большинства каравансараев лежит обширный двор, окруженный мощными стенами, к которым изнутри пристроены различные помещения. При этом существуют различные варианты этого планировочного принципа. Такие каравансараи образуют первую группу.

Однодворовые караван-сараи, по мнению Н.Б. Немцевой [Немцева 1977 , с. $163 ; 1983$, с. 136-137], являются прямыми наследниками Омейадских и Аббасидских укрепленных крепостей (рибатов) и замков. А те, в свою очередь, были построены по образцу римских пограничных фортов, которые были квадратными в плане с круглыми башнями по углам и полукруглыми в середине стен. При общем сохранении этого планировочного принципа архитектура караван-сараев может быть весьма разнообразна.

Относительно простую планировку имеет караван-сарай IX в., построенный из сырцового кирпича на восточной дороге, ведущей в Пайкенд [Мухамеджанов и др., 1988, c. 116-147; Хмельницкий, 1992 , c. 180-182]. Он представлял собой почти квадратное $(75 \times 72$ м) в плане здание с двумя входами - с южной и северной сторон (рис. 1,1$)$. Главный южный вход оформлен выступающим порталом-пештаком, по углам пристроены небольшие декоративные круглые башни. Бо́льшую часть караван-сарая занимал обширный двор, в котором располагались платформы для разгрузки и погрузки товаров. Вдоль южной, восточной и западной стен находились жилые и хозяйственные помещения. Комнаты для гостей были сгруппированы в секции, которые состояли из айвана и соединенных с ним двух спален с суфами. Между секциями находились хозяйственные (складские) помещения, соединенные с двором широкими сводчатыми проходами. Справа от южного входа было устро- 

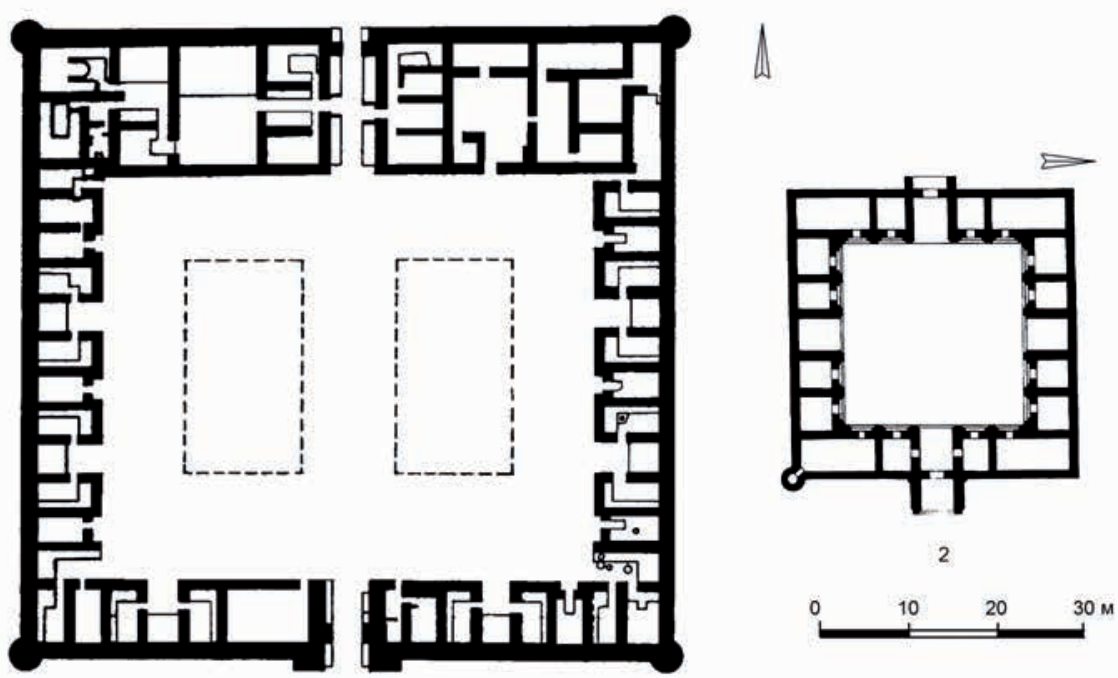

Рис. 1. Однодворовые караван-сараи Средней Азии. 1 - Пайкенд, IX в.; 2 - Суран, XI-XII вв. (по: [Хмельниикий, 1992])

Fig. 1. One-yard caravanserais of Central Asia. 1 - Paikend, IX c .; 2 - Suran, XI - XII centuries (by: [Khmelnitsky, 1992])

ено двухкомнатное жилище привратника, а слева - большое помещение, в котором могла находиться мечеть. К северной стене пристроена сложно устроенная группа помещений, среди которых исследователи выделяют купальню, зал для собраний, «языческую капеллу» [Хмельницкий, 1992, c. 181-182].

Более простую планировку имеет караван-сарай Суран (ОдеМергень) XI-XII вв., расположенный в пустынной местности на дороге из Мерва в Хорезм [Пугаченкова, 1963, c. 234-238; Хмельницкий, 1996, c. 295-297]. Стены его, сложенные из сырца, ограничивают пространство $41 \times 41,5$ м (рис. 1, 2). Юго-восточный угол фланкирован небольшой сторожевой башней, с восточной и западной сторон находятся два входа, оформленные порталами. Внутри к входным айванам примыкают небольшие, почти квадратные комнаты для гостей и обширные складские помещения вытянутой, прямоугольной формы. Здесь мы имеем двор с четырьмя айванами - планировочный принцип, применяемый на Востоке в зданиях различного назначения. Караван-сараи у Пайкенда и Суран не похожи на крепости: у них по два входа, а башни сильно редуцированы и носят, скорее, декоративный характер.

Пример сильно укрепленного караван-сарая являет собой известный памятник Дая-Хатын, расположенный в Туркменистане, на караванной дороге, ведущей из Мерва и Амуля в Хорезм [Пугаченкова, 1958а, c. 230-241; Хмельницкий, 1992, c. 182-187]. Здание имеет два обвода стен. Внешние стены, сложенные из сырцового кирпича, охватывают прямоугольник размерами $112 \times 125$ м. По углам они укреплены круглыми башнями, а к сторонам пристроены пря- 
моугольные контрфорсы (рис. 2, 1). Почти посредине расположен караван-сарай квадратной в плане формы $(53 \times 53$ м $)$ с углами, фланкированными круглыми башнями и полукруглыми башнями посредине юго-восточного и северо-западного фасадов (рис. 2, 2). Стены сложены из сырца, а облицовки стен и кладки арок сводов и куполов выполнены из жженого кирпича. В центре северо-восточного фасада находится высокий пештак со стрельчатым сводом (рис. 2, 3). Арка входа ведет в квадратный двор, обведенный по периметру сводчатой галереей и группой разнообразных помещений (рис. 2, 4). На осях двора лежат четыре айвана с высокими стрельчатыми сводами. Дая-Хатын исследователи датируют по-разному - от X до XII в.

К группе однодворовых построек относится большинство известных караван-сараев домонгольского времени (рис. 3).

Вторая группа караван-сараев представлена двухчастной (двухдворовой) композицией с двумя или четырьмя айванами по сторонам двора. Истоки ее Н.Б. Немцева выводит из древнеиндийской строительной культуры Хараппа. Затем такая планировка проявляется в древней Бактрии, а позже - в древних и раннесредневековых буддийских двухчастных монастырях Тохаристана [Немцева, 1983, с. 137]. По мнению Б.А. Литвинского, двухчастная четы- 


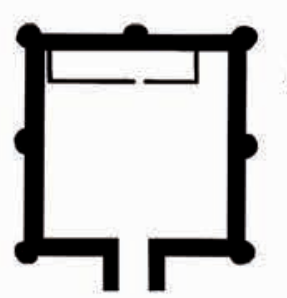

1

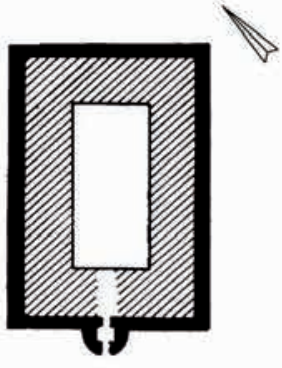

5

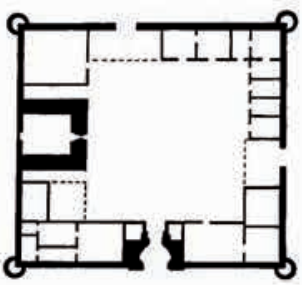

8

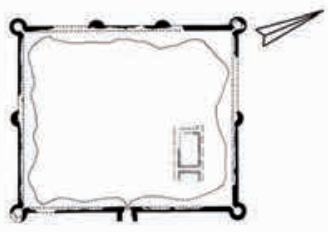

11

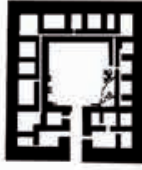

2

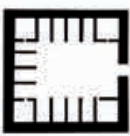

3

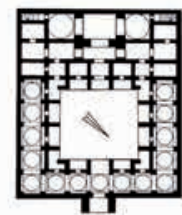

6

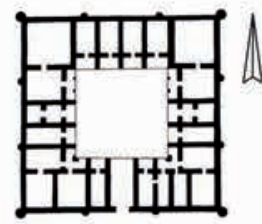

9

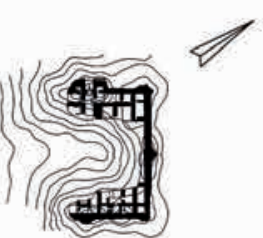

12

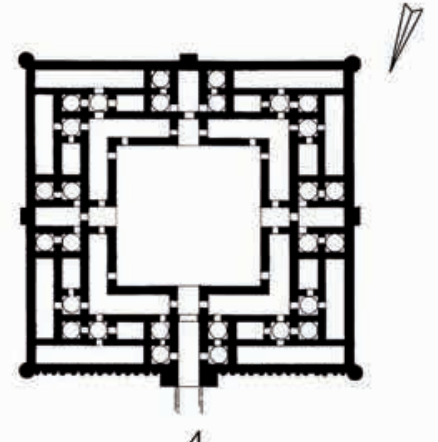

4

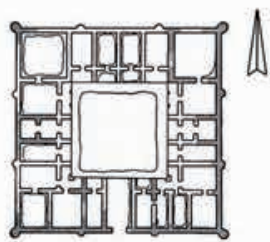

7

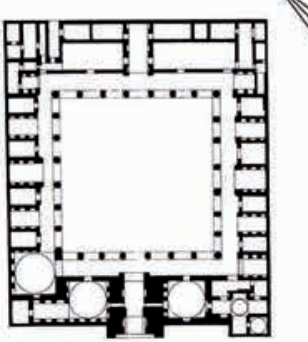

10

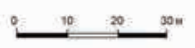

Рис. 3. Однодворовые караван-сараи Средней Азии. 1 - Сан-Таш, X-ХII вв.; 2 - CарыБулун, XI-XII вв.; 3 - Май-Тор, X-ХII вв.; 4 - Чалдьквар, X-XII вв.; 5 - Сули-тепе,

X-XII вв.; 6-Ал Аскер, X-ХІІ вв.; 7 - в Дахистане, X-ХІІ вв.; 8 - в Дербенте, X-XII вв.; 9 -южный в Мисриане, X-ХІІ вв.; 10 - восточный в Мисриане, X-ХІІ вв.; 11 - Даш-кала, X-ХII вв.; 12 - Ииан-рабат IX-XI вв. (по: [Хмельниикий, 1997])

Fig. 3. One-yard caravanserais of Central Asia. 1 - San Tash, X-XII centuries; 2 - Sary-Bulun, XI-XII centuries; 3 - Mai-Tor, X-XII centuries; 4 - Chaldykvar, $X$-XII centuries; 5 - Suli-tepe, $X$-XII centuries; 6 -Al Asker, X-XII centuries; 7 - in Dahistan, $X$-XII centuries; 8 - in Derbent, $X$-XII centuries; 9 - southern in Misriana, X-XII centuries; 10 - eastern in Misriana, X-XII centuries; 11 -Dash-Kala, X-XII centuries; 12 - Ishan-Rabat IX-XI centuries (by: [Khmelnitsky, 1997]) 

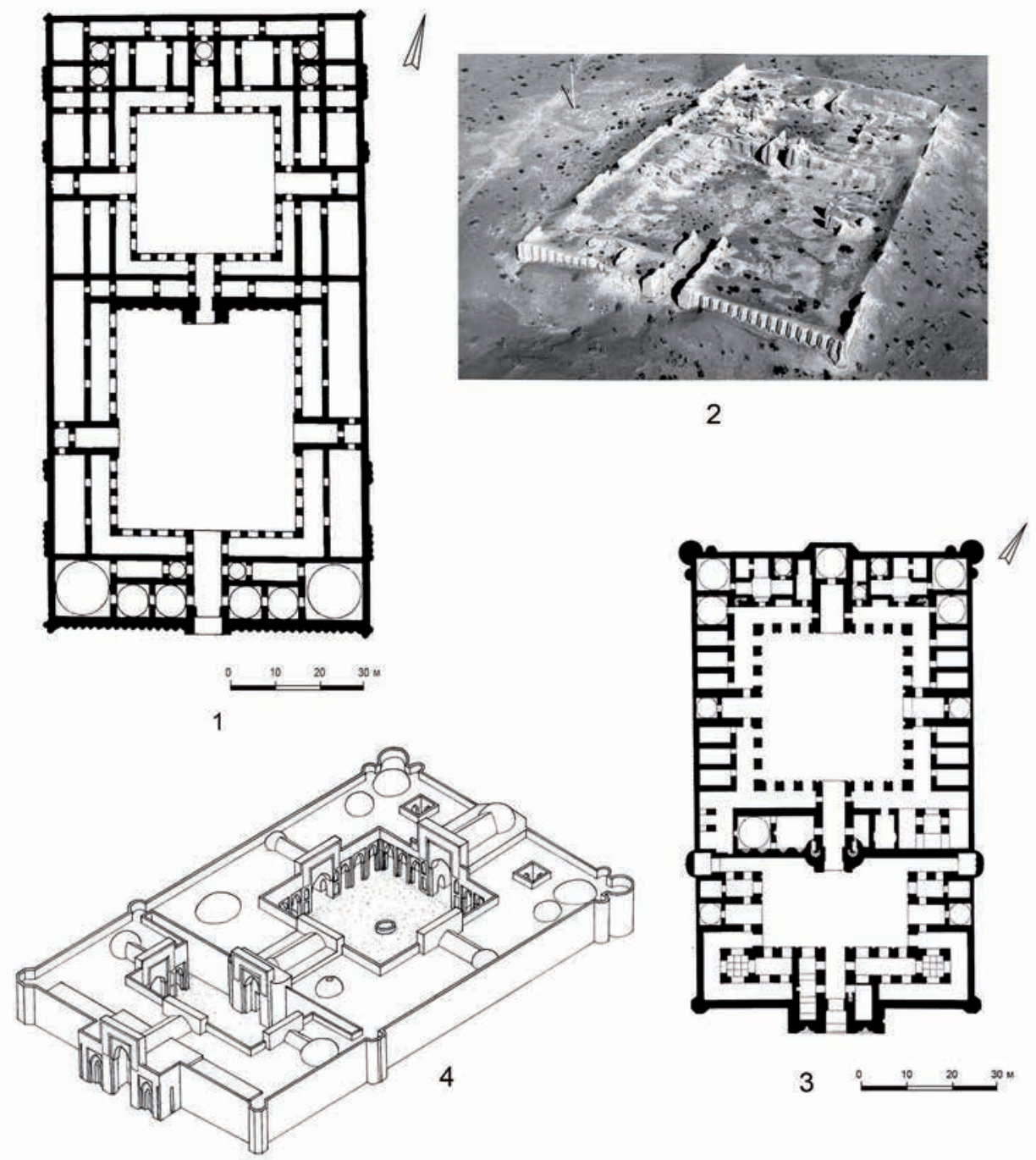

3

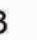

Рис. 4. Двухдворовые караван-сараи XI-ХІІ вв. 1 - Акча-кала, план (nо: [Пугаченкова, 1958а]); 2 - Акча-кала аэрофото; 3 - Рабат-и Шараф план; 4 - Рабат-и Шараф аксонометрия (no: [Hillenbrand, 1994])

Fig. 4. Two-yard caravanserais of the XIth-XIIth centuries. 1 - Akcha-Kala, plan (by: [Pugachenkova, 1958a]); 2 - Akcha-kala aerial photo; 3 - Rabat-i Sharaf plan; 4 - Rabat-i Sharaf axonometry (by: [Hillenbrand, 1994])

рехайванная планировка буддийских монастырей, лишившись ступы и утратив культовую принадлежность, воплотилась в караван-сараях XIXII вв. [Литвинский, Зеймаль, 2010, c. 108-112].

К группе двухдворовых построек XI-XII вв. относится караван- сарай Акча-кала, расположенный на тракте Мерв-Амуль (Туркменистан) [Пугаченкова, 1958a, с. 225-230; Хмельницкий, 1996, с. 293-295]. Он прямоугольный в плане, размерами $150 \times 80$ м (рис. 4, 1-2). Пахсовые стены его декорированы гофрами, а углы укреплены также гофрирован- 


\section{ҚАЗАҚСТАН АРХЕОЛОГИЯСЫ № 2 (4) 2019}

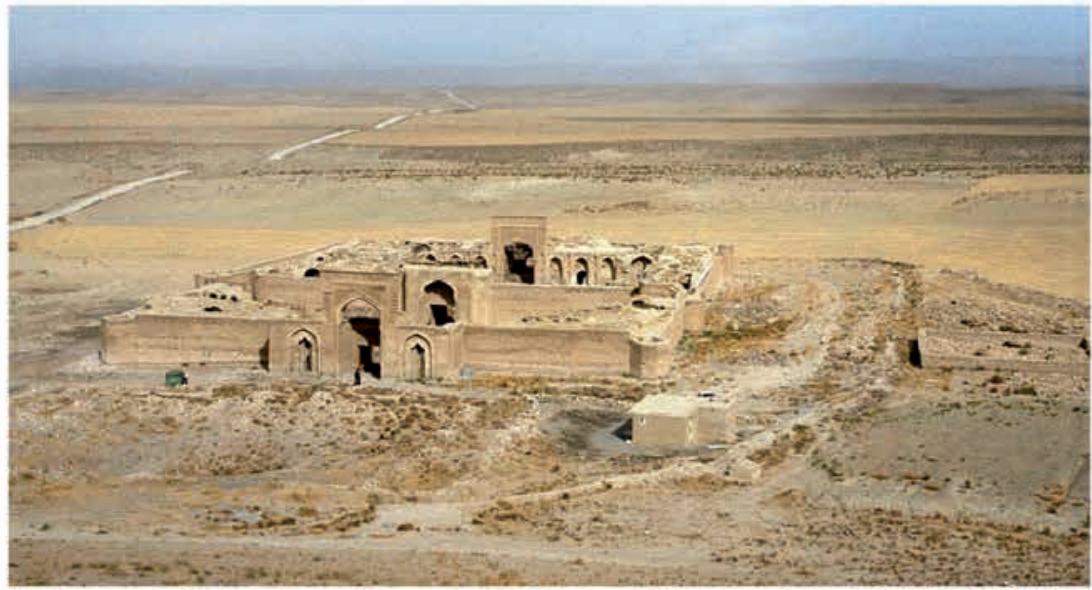

1

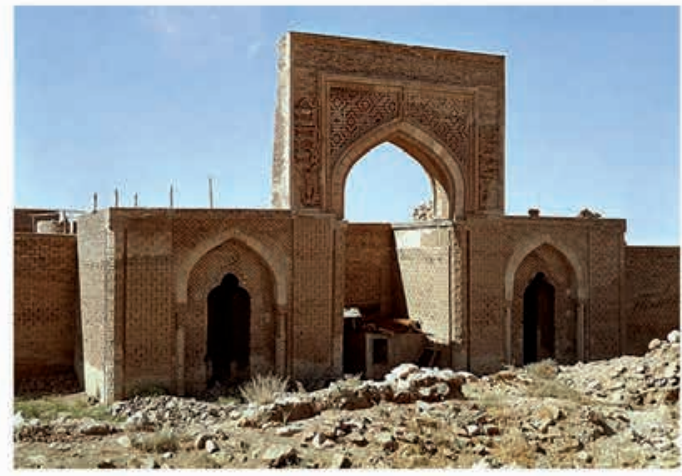

2

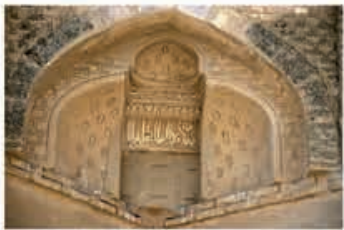

3

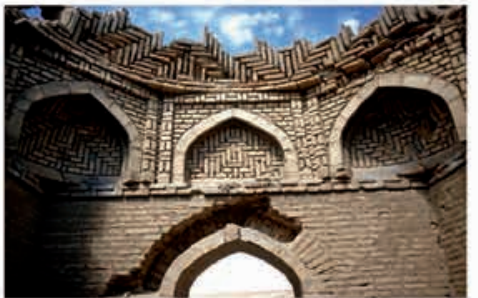

4

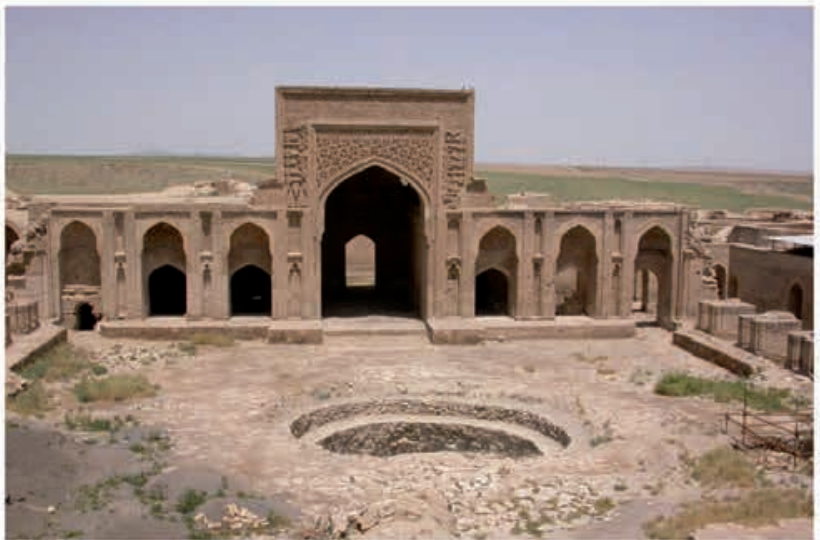

5

Рис. 5. Рабат-и Шараф. 1 -аэрофото; 2 -портал; 3 - тромп; 4 - купольное помещение; 5 - второй двор

Fig. 5. Rabat-i Sharaf. 1 -aerial photo; 2 - portal; 3 - tromp; 4 -dome room; 5 -second yard 
ными прямоугольными башенными выступами. За портальным входом с южной стороны следовал широкий коридор, по сторонам которого находились самые репрезентативные помещения, вероятно общественного характера. Проход вел в передний четырехайванный двор прямоугольной формы, окруженный с трех сторон арочной галереей на прямоугольных столбах. Вдоль наружных меридиональных стен находились длинные прямоугольные помещения, вероятно, предназначенные для размещения скота и поклажи. Северная стена представляла собой архитектурно разработанный фасад второй части здания. Посреди этого дворового фасада находился выступающий вперед портал-пештак с широкой входной нишей. Второй квадратный двор караван-сарая со всех сторон окружен арочной галереей и расширен осевыми айванами. В северной части, вероятнее всего, находились комнаты для гостей.

Сходную планировку имеет караван-сарай Рабат-и Шараф (рис. 4, $3-4 ; 5)$, построенный в начале XII в. на пути из Мерва в Нишапур [Пугаченкова, 1958a, с. 230; Хмельницкий, 1996, c. 295-296; Hillenbrand, 1994, p. 342-345].

Настоящим шедевром средневекового зодчества является каравансарай Рабат-и Малик или царский рабат, расположенный на одной из важных дорог, соединяющих Бухару и Самарканд. Н.Б. Немцева относит его то к многодворовым [Немцева, 1977, c. 165], то к двухдворовым каравансараям [Немцева, 1983, с. 140-142]. Как и караван-сарай Дая-Хатын, он имел двойной обвод стен. Внешние сырцовые стены образовывали прямоугольник размерами примерно $150 \times 200$ м. Внутри этих укреплений находилось здание караван-сарая размерами $89 \times 91$ м. В центре южной фасадной стены находился портал, который представлял собой широкую арочную нишу со стрельчатым завершением и проходом в задней стене. По сторонам от портала поверхность фасадной стены была декорирована гофрами. По углам здания пристроены круглые башни гульдаста, одна из которых (юго-западная) дожила до 1930-х гг. (рис. 6, 1).

Внутри постройка была разделена на две части, северную и южную. В процессе существования здание претерпело кардинальную перестройку. В первом периоде (рис. 6, 2) южная часть представляла собой обширный открытый двор. Остатки помещений были зафиксированы только вдоль южной стены и входного айвана. Северная часть здания состояла из трех частей. В центре средней части был расположен дворик, окруженный арочной галереей с четырьмя айванами по сторонам. С трех сторон за галереей находились небольшие комнаты, скорее всего, предназначенные для гостей, а к южной стене примыкали два больших помещения, возможно, общественного характера. Боковые части представляли собой дворы с небольшими комнатами с северной и западной сторон.

Во втором периоде Рабат-и Малик был кардинально перестроен (рис. 6, 3-4). В южной части образовались два блока хозяйственных помещений. Наиболее значительно перестроен центральный двор северной части. На месте аркады построена многокупольная галерея с восьмигранной ротондой в центре. Они, несомненно, являлись парадными помещениями, которые придавали постоялому двору сходство с дворцовым зданием. Н.Б. Немцева 


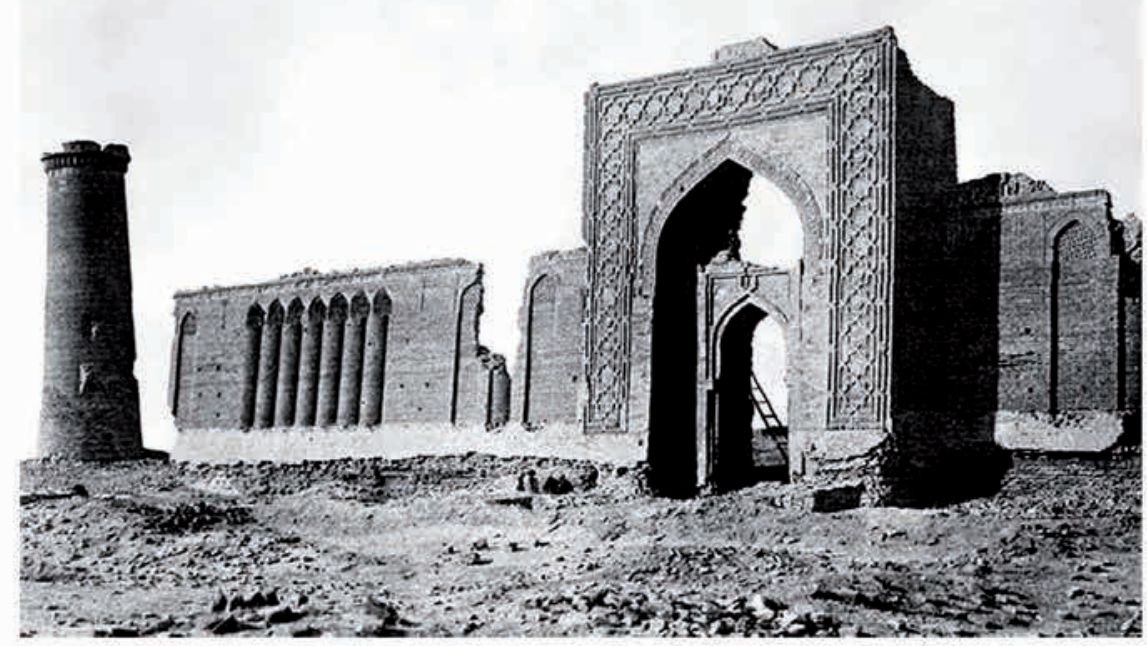

1
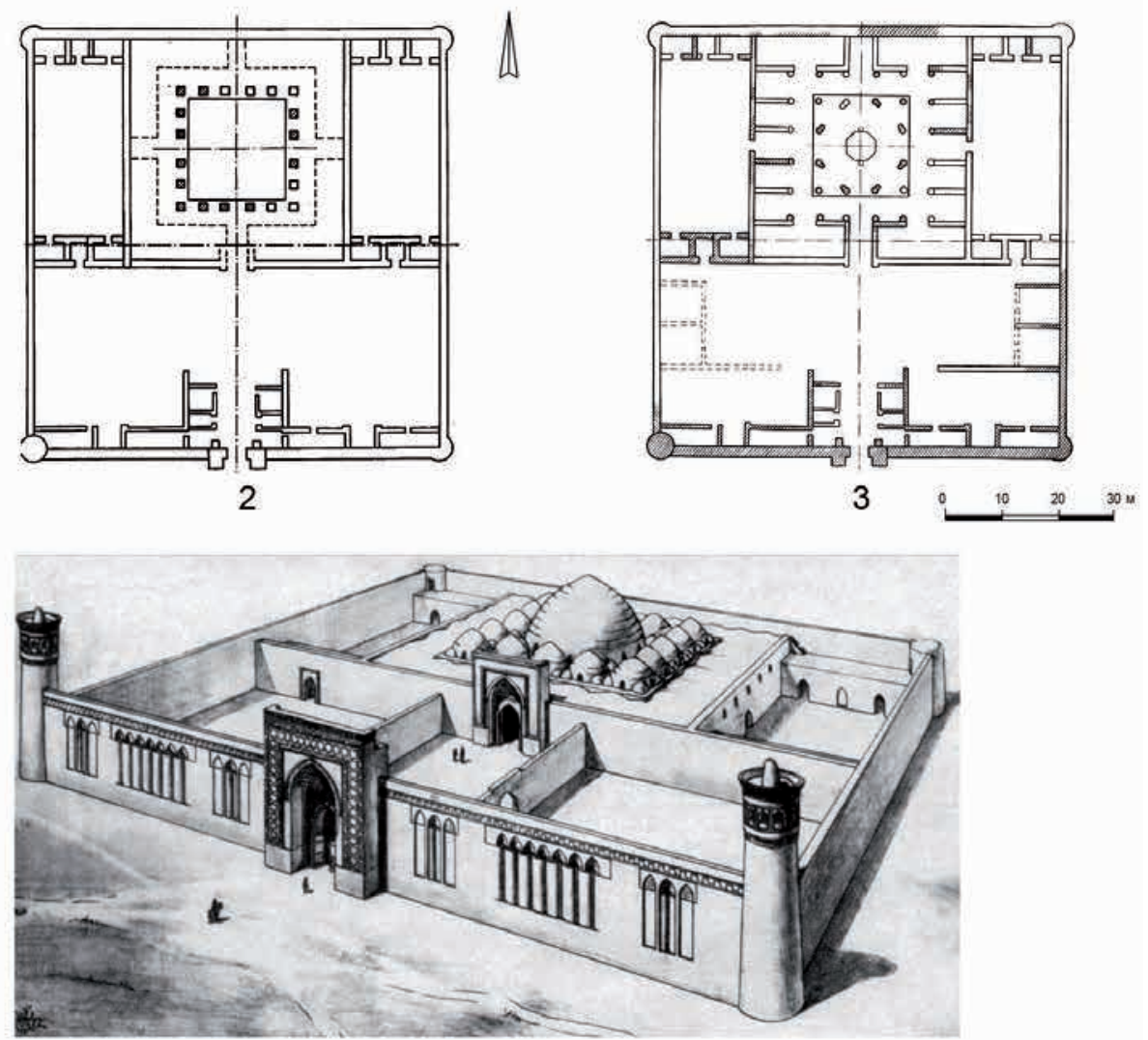

4

Рис. 6. Рабат-и Малик. 1 - фотографии фасадной части; 2 - план І периода; 3 - план II периода; 4 - реконструкция II периода (по: [Немиева, 1983])

Fig. 6. Rabat and Malik. 1 -photos of the front part; 2 - plan I period; 3 - Plan II period; 4 - reconstruction of the II period (by: [Nemtseva, 1983]) 


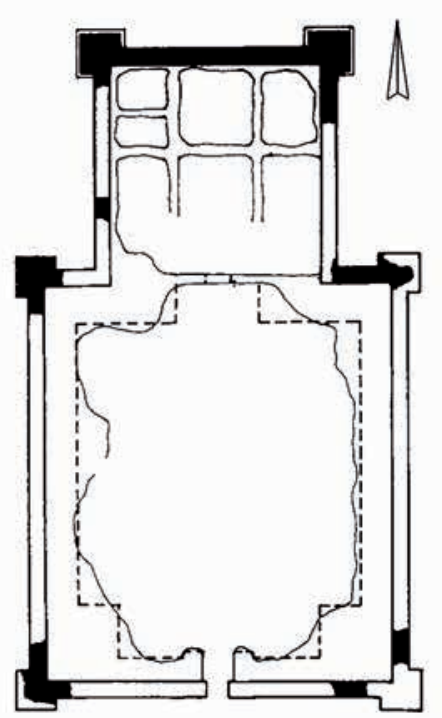

1

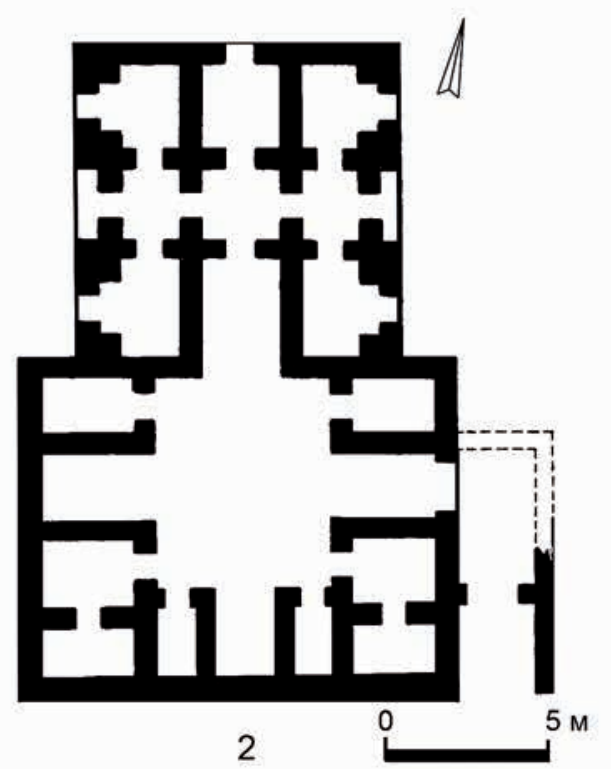

Рис. 7. Двухчастные караван-сараи. 1 - Чаш-кала, Х в. (по: [Хмельниикий, 1992]); 2 - Куртльь, ХІ в. (по: [Хмельницкий, 1996])

Fig. 7. Two-part caravanserai. 1 - Chal-Kala, Xc. (by: [Khmelnitsky, 1992]); 2 - Kurtly, XI century (by: [Khmelnitsky, 1996])

считает, что Рабат-и Малик был возведен в XI в., перестроен в начале XII в. и просуществовал в таком виде до XVIII столетия [Немцева, 2010, c. 267-311].

К двухчастным постройкам относятся караван-сараи Чаш-кала Х в. в Южном Туркменистане и на городище Куртлы (средневековый Башан) XI в. [Пугаченкова, 1958 a, с. 241242; 1958б, с. 290-294; Хмельницкий, 1992, с. 194; 1996, с. 298-299], но их планировка принципиально отлична (рис. 7, 1). Здания представляют собой не единый объем, а состоят из двух частей различной ширины. В южной части находится открытый двор с помещениями вдоль трех стен. Северная, более узкая часть, в плане представляет собой квадрат с центральным помещением квадратной формы, к которому примыкают девять окружающих его комнат. Все комнаты перекрыты сводами. Как отмечают исследователи [Хмельницкий, 1996, с. 298], такая центрическая планировка характерна для жилого замка-кёшка доисламского и раннемусульманского периодов [напр., Пугаченкова, 1958a, с. 206-212].

К третьей группе по Н.Б. Немцевой относятся круглые в плане караван-сараи, которые известны только на территории Хорезма. Это караван-сараи Дэу-кала (рис. 8, 1), Орта-кую, Талайхан-ата (рис. 8, 2) и Ак-Яйла [Толстов, 1948, с. 166; Вишневская, 1958, с. 431-466]. Датируются они XI - началом XIII в., но некоторые использовались и в золотоордынский период. Внешние стены этих зданий, толщина которых достигала 2 м, образовывали круг диаметром 50-60 м. В середине нахо- 


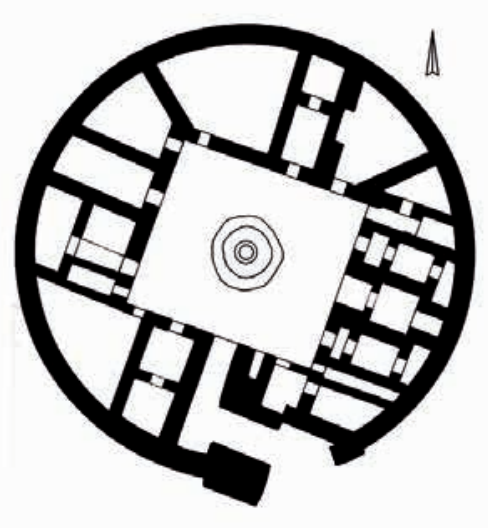

1

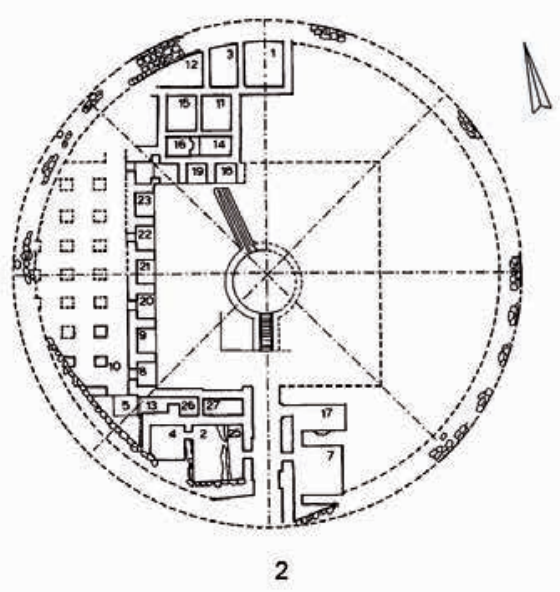

02030 ,

Рис. 8. Круглье караван-сараи. 1 - Дэу-кала, ХІ-ХІІІ вв. (по: [Толстов, 1948]); 2 - Тайлахан-ата (XI-XIV вв.) (по: [Вишневская, 1958])

Fig. 8. Round caravanserai. 1 - Daewoo-Kala, XI-XIII centuries. (by: [Tolstov, 1948]); 2 - Taylakhan-ata (XI-XIV centuries) (by: [Vishnevskaya, 1958])

дился двор квадратной или прямоугольной формы, который окружали помещения различного назначения и сложной формы. В центре двора был выкопан колодец или наливная цистерна. Столь необычную форму хорезмийских караван-сараев Н.Б. Немцева связывает с традицией возведения функционально иных, но сходных по форме построек древнехорезмского и сакского периодов (Кой-Крылган-кала, круглые здания на Калалы-Гыр-2 и Гяур-кале, мавзолеи Тагискена, Чирик-Рабата, Баланды-3) [Немцева, 1983, с. 137].

Территорией, по которой проходили многие караванные пути, являлось Армянское нагорье. Каравансараи строились вдоль дорог и в крупных торговых городах. Архитектура армянских караван-сараев отличается своеобразием: здесь был выработан оригинальный тип закрытого зального караван-сарая [Халпахчьян, 1959 , c. $105-133$; 1971 , с. 185-210].
В плане они представляли собой вытянутые прямоугольные здания, перекрытые сводами, подпружные арки которых опираются на прямоугольные в плане пилоны или устои. Зальные караван-сараи делятся на однонефные и трехнефные, причем у трехнефных центральный неф обычно выше боковых (рис. 7; 8). К этому типу построек относится большинство придорожных гостиниц Армении: Ахкенда (XII-XIII вв.), Яйджи (1343 г.), Селима (1332 г.), Неркин Джерати (XIII в.), Аруча (XIII в.), Зора (XIII в.) и др.

Так как здания должны были защищать караваны от нападений, наружные стены делались относительно толстыми, иногда их усиливали полукруглыми контрфорсами, напоминающими крепостные башни. Возводились здания из хорошо обработанного камня, базальта или туфа различных оттенков. Вход в помещение был один, обычно с торцевой сто- 


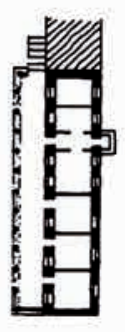

1

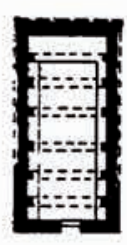

4

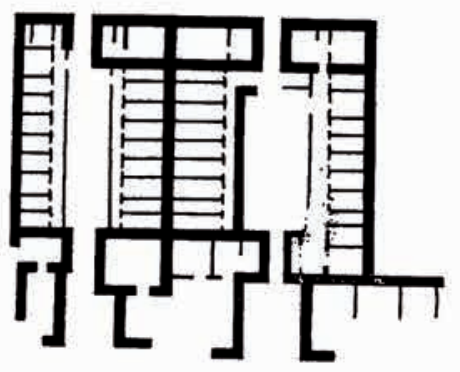

2

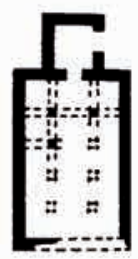

5

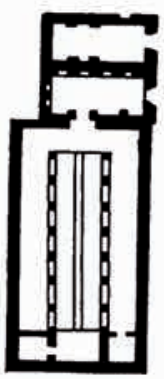

6

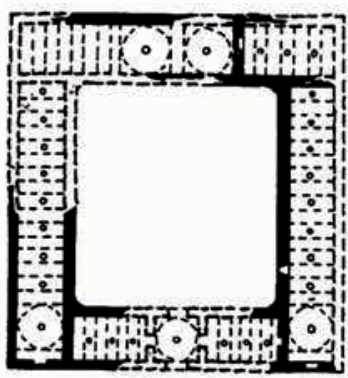

3

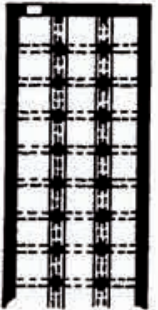

7

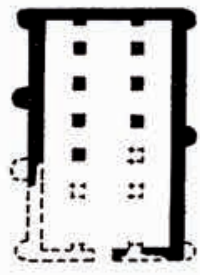

8

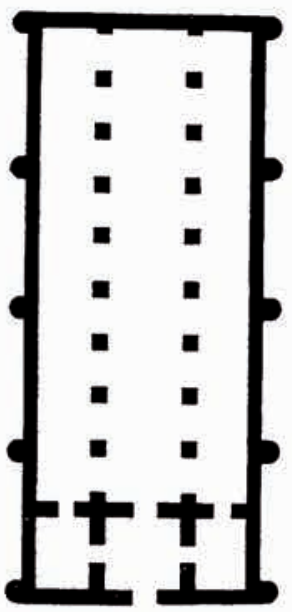

9

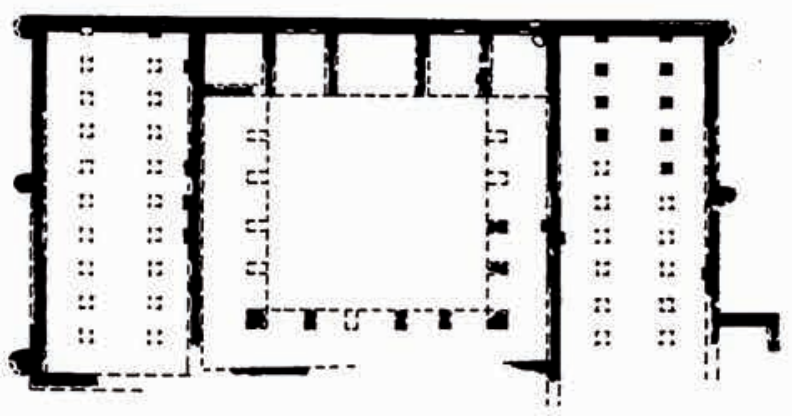

10

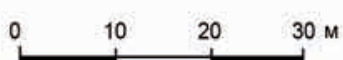

Рис. 9. Городские $(1,2)$ и придорожные караван-сараи Армении (3-10). 1 - Гегарда, ХIХ в.; 2 - Ани, ХІІІ в.; 3 - Атарбекяна, ХII-XIII вв.; 4-Ахкенда, XII-XIII вв.; 5 -Яйджи, 1343 г.; 6-Селима, 1332 г.; 7 - Неркин Джарапи, ХІІІ в.; 8-Аруча, ХІІІ в.; 9-Зора, ХІІІ в.; 10 - Неркин Талина, ХIII-ХIV вв. (по: [Халпахчьян, 1971])

Fig. 9. Urban $(1,2)$ and roadside caravanserais of Armenia (3-10). 1 - Geghard, XIX century; 2 - Ani, XIII century; 3 - Atarbekyan, XII - XIII centuries; 4 - Ahkend, XII - XIII centuries; 5 - Yaydzhi, 1343; 6-Selim, 1332; 7 - Nerkin Jarapi, XIII century; 8 - Arucha, XIII century; 9 - Zora, XIII century; 10 - Nerkin Talina, XIII - XIV centuries (by: [Khalpakhchyan, 1971]) 
роны. Сводчатые перекрытия имели, чаще всего, полуциркульное очертание, реже - стрельчатое. Крыша, как правило, делалась двускатная, небольшого уклона и покрывалась каменными плитами, обработанными в форме черепицы. Отапливались караван-сараи жаровнями, в некоторых из них найдены небольшие очаги в виде каминов и тониров. Свет поступал в помещения через небольшие, расширяющиеся к низу проемы в шелыгах сводов.

В однонефных караван-сараях люди, товары и животные размещались в одном большом зале. В трехнефных постройках животные находились в боковых галереях, где для них были поставлены ясли и корыта для воды. В центральной части здания посредине был сделан желоб для жаровен, а на окружавших его с двух сторон возвышениях на кошмах и паласах размещались люди.

Кроме зальных, в Армении существовали и типичные для Среднего Востока караван-сараи дворового плана, но они строились преимущественно в городах.

Еще одним регионом, лежащим на пересечении караванных путей, была Малая Азия. В сельджукское и более позднее время здесь строилось множество караван-сараев, многие из которых сохранились до наших дней. Малоазийские каравансараи относятся к трем типам [ВИА, 1969, с. 434-436; Hillenbrand, 1994, p. 346-350]. Здесь есть характерные для Среднего Востока постройки с внутренним двором (рис. 9, 1-2) и зальные здания, сходные с армянскими караван-сараями (рис. 9, 3-10). Третий, наиболее распространенный в Малой Азии тип караван-сараев, представляет собой синтез двух предыдущих. К прямоугольному зда- нию дворовой композиции, напротив входного проема пристраивался крытый прямоугольный зал вытянутых пропорций (рис. 9, 11-18). Вход в него также оформлялся порталом, сводчатое перекрытие покоилось на колоннах или столбах, а в центральной части находился световой фонарь. В середине двора ставилась маленькая открытая мечеть-киоск на четырех арках с купольным перекрытием. Ханы возводились из рваного камня, фасады стен, столбы и арки облицовывались тесаными каменными блоками.

Самым известным и наиболее выразительным примером здания этого типа является Султан-хан (1229 г.) на пути из Коньи в Аксарай (рис. 11, 11; 12) [Stierlin, 1998, p. 62-75]. К этому же типу относятся Палаз-хан (1236 г.) на пути из Кайсери в Сивас, Казилвиран (1207 г.) на дороге Конья Бейшехир, Сасадин-хан (1236 г.) возле Коньи и мн. др.

Несмотря на то, что существует достаточно много обобщающих работ, в которых собраны и проанализированы караван-сараи различных стран Востока [Халпахчьян, 1959 , с. $105-133$; 1971, с. 185-210; Хмельницкий, 1992, с. 180-204; 1994, c. 289-316; Hillenbrand, 1994, p. 331-376], до сих пор не создана классификация этой очень важной для средневекового зодчества категории зданий.

Н.Б. Немцевой [Немцева, 1977, c. $163-165 ; 1983$, с. 136-142] были выделены три группы для каравансараев Средней Азии: однодворовые, двухдворовые и круглые в плане. Кроме того, что это деление весьма условно и не отражает все многообразие планировок, такая классификация в корне не верна, так как здесь не выдерживается общий принцип 
Зиливинская Э.Д. Караван-сараи: генезис, региональные особенности, классификация

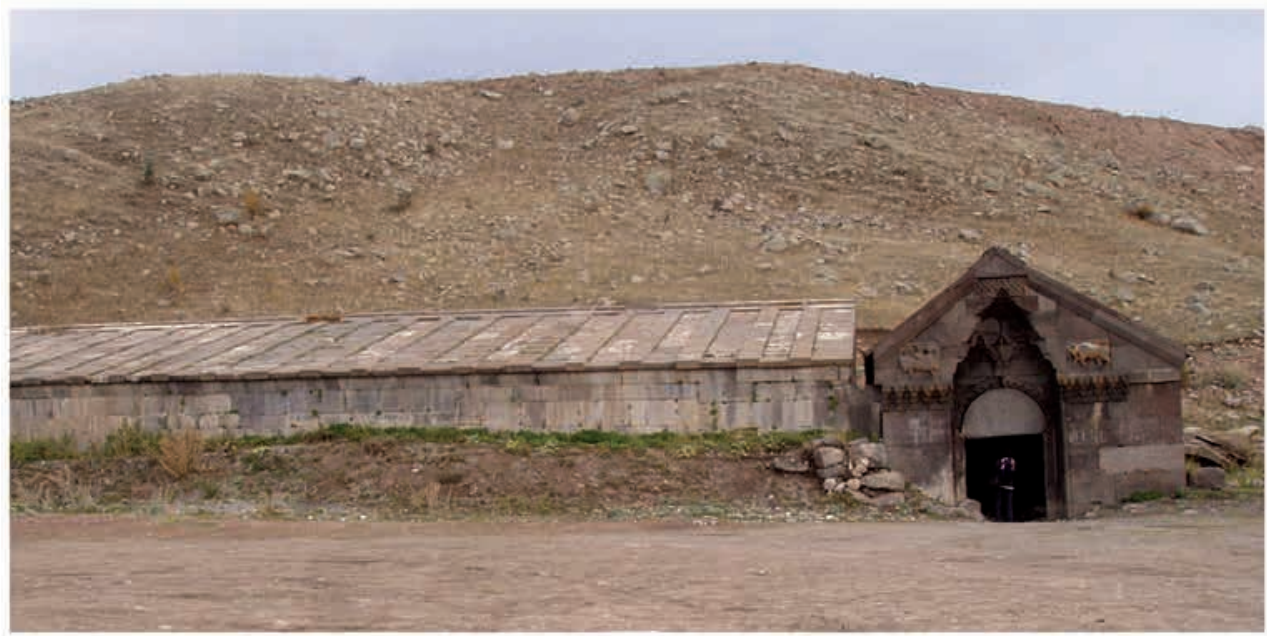

1

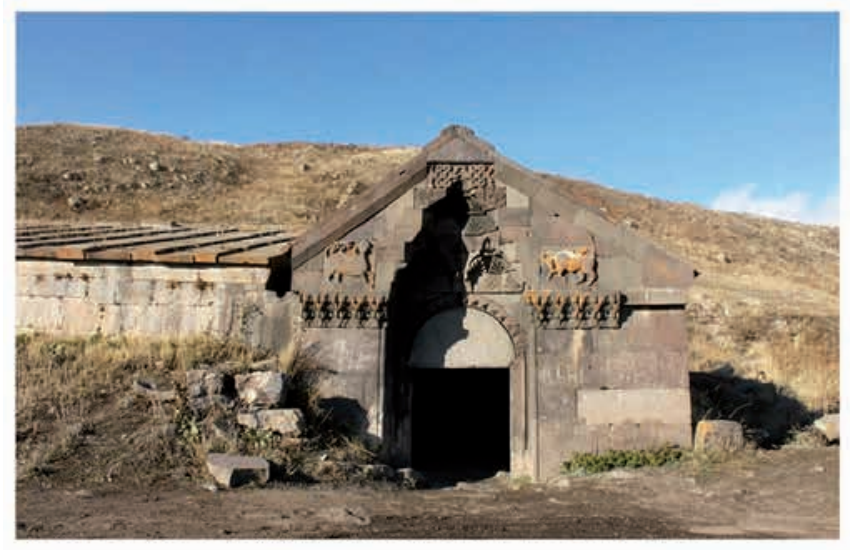

2

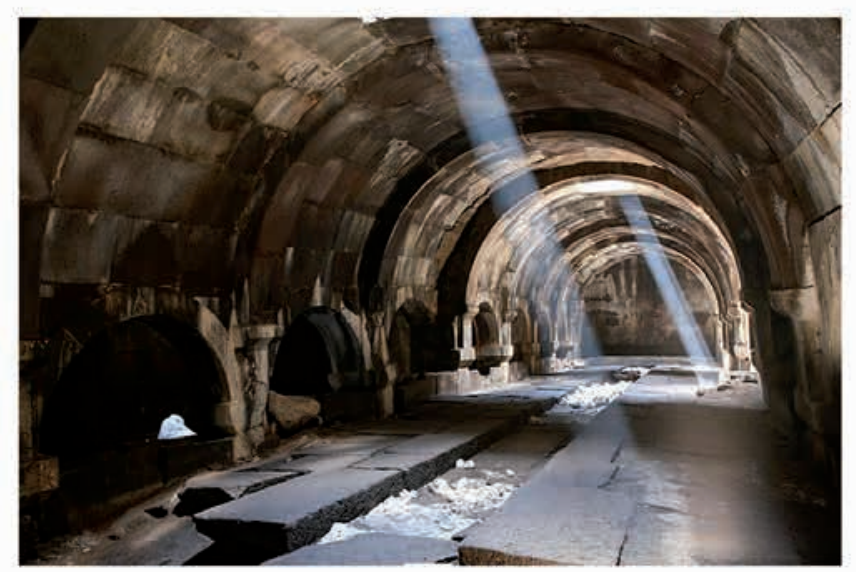

3

Рис. 10. Караван-сарай Селима, ХІІІ в. 1 - общий вид; 2 - портал; 3 - интерьер Fig. 10. Selim caravanserai, XIIIth century. 1 -general view; 2 - portal; 3 -interior 

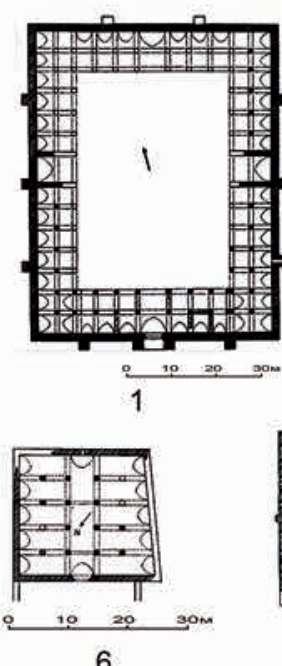

6
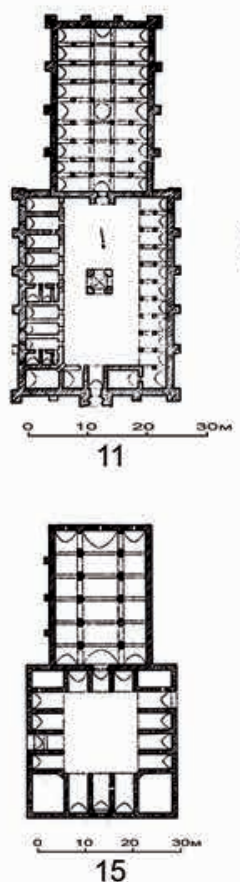
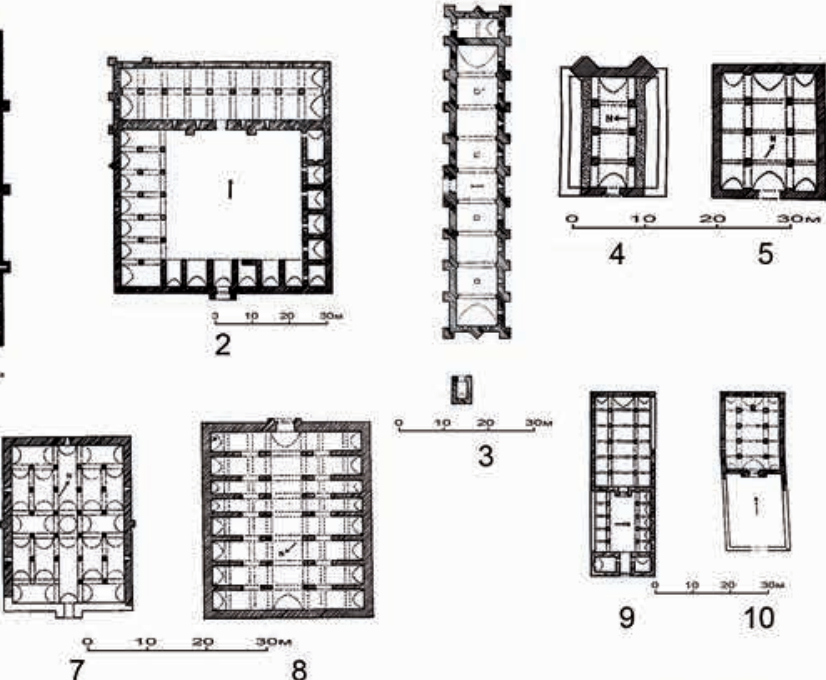

7
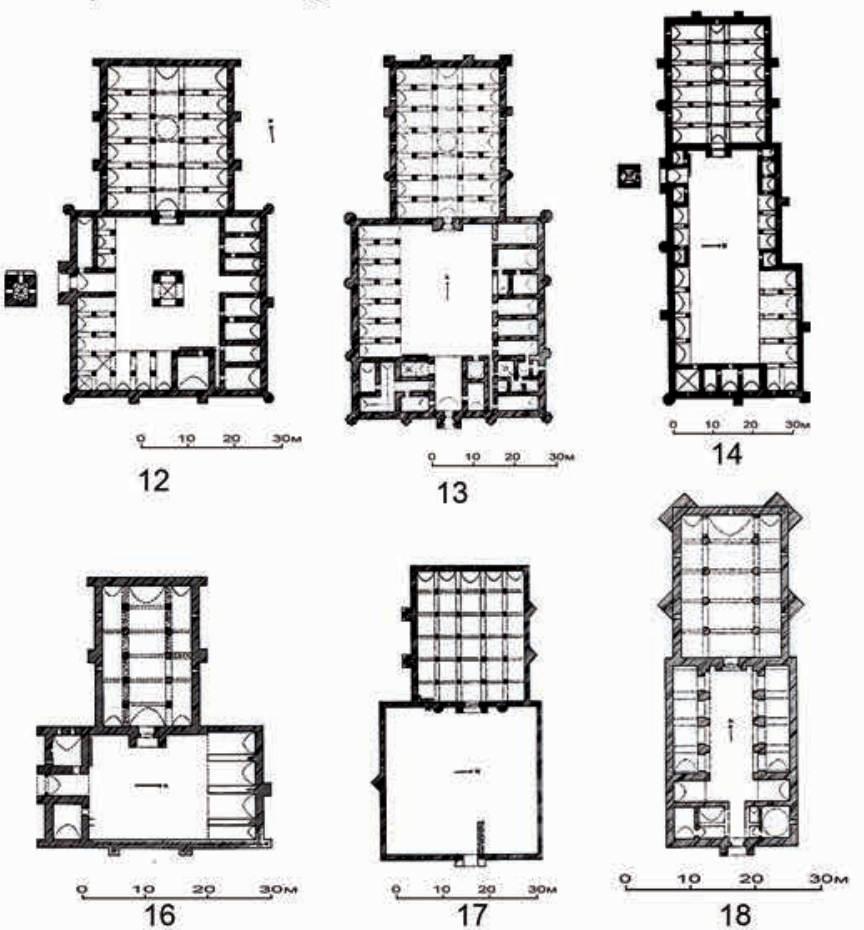

Рис. 11. Караван-сараи Малой Азии дворовые (1-2), закрытые (3-10), комбинированные (11-18). 1- Эвдир-хан; 2 -Карджи-хан; 3 -Шарафша-хан; 4 - Енисекёй-хан; 5 -Куру-хан; 6-Долай-хан; 7 - Оресин-хан; 8- Зиварик-хан; 9 - Куручешме-хан;

10 - Неркийи Джрапи; Султан-хан; 12 - Аджикара-хан; 13 - Каратай-хан; 14 - Зазадин-хан; 15 - Хаким-хан; 16 - Киршехир Кесик Копрю-хан; 17 - Чардак-хан; 18 - Эртохуш-хан (no: [Hillenbrand, 1994])

Fig. 11. Caravanserai of Asia Minor with yard (1-2), closed (3-10), combined (11-18). 1 - Evdir Khan; 2 - Karji Khan; 3 - Sharafsha Khan; 4 - Yenisekoy Khan; 5 - Kuru-han; 6-Dolay Khan; 7 -Oresin Khan; 8 -Zivarik Khan; 9 -Kurucheshme Khan; 10 - Nerkii Jrapi; Sultan Khan; 12 - Ajikara Khan; 13 - Karatay Khan; 14 -Zazadin Khan; 15 - Khakim Khan; 16-Kirshehir Kesik Kopru-han; 17 -Chardak Khan; 18 -Ertohush Khan (by: [Hillenbrand, 1994]) 
выделения признаков: в двух случаях определяющим является количество дворов, а в третьем - форма плана.

Более подробная классификация была выработана Л.Ю. Маньковской [Маньковская, 1980, с. 57-67; 2014, с. 200-206]. Исследовательница выделяет три основные группы. К первой группе относятся здания, сочетающие многокамерное центрическое здание с двором (Чаш-кала Х в., Куртлы XI в.). Вторая группа - это многокамерные здания с Т-образным расселением. К ней относится единственный памятник Таш-рабат (XXII вв.), расположенный в Кыргызстане, в горах Тянь-Шаня [Хмельницкий, 1996, с. 282-287]. К третьей группе относятся постройки дворового плана, которые, в свою очередь, делятся на однодворовые и многодворовые. Однодворовые исследовательница разделяет по принципу застройки по сторонам двора. Застройка может быть секционной, галерейной или (наиболее частый вариант) галерейно-секционной. Вторая подгруппа (многодворовые здания) делится на двухдворовые, с четырьмя равновеликими дворами (Яр-Бекир XII-XIII вв.), с центральным проезжим двором (Акыр-таш) и с Т-образным внутренним членением (Рабат-и Малик).

Классификация Л.Ю. Маньковской, несомненно, более подробная и совершенно верно отражающая некоторые особенности планировки, тоже не является стройной иерархической системой и не включает в себя все признаки, присущие зданиям средневековых караван-сараев. Мне представляется, что, используя некоторые типологические принципы систем Н.Б. Немцевой и Л.Ю. Маньковской, можно создать классификацию планировки караван-сараев, примени- мую к большинству построек этой категории на всем средневековом Востоке.

Предлагаемая типология основывается исключительно на планиметрии построек, объемнопространственные характеристики не рассматриваются. В предлагаемой классификации используются следующие признаки: наличие или отсутствие открытого двора, количество дворов, форма плана, количество входов, застройка двора, расположение помещений, наличие колоннады.

Bce здания караван-сараев можно разделить на три большие группы: I - открытые (дворовые); II - закрытые; III - синтетические, то есть состоящие из открытого двора с застройкой и пристроенной к нему закрытой части.

I. Первая группа наиболее многочисленная и разнообразная по планировке. Она делится на три подгруппы: I* - однодворовые постройки; I** - двухдворовые; I*** - многодворовые.

Каждая подгруппа, в свою очередь, разделяется на отделы по форме плана. Здания могут быть: А - квадратные (или близкие к квадрату) в плане; В - прямоугольные, сильно вытянутые в плане; C - круглые в плане. В каждом отделе может быть подотдел по количеству входов: $\mathrm{V}$ - один вход; W - сквозной проезд, то есть два входа.

Далее следуют порядки, которые отражают застройку вдоль стен двора: s - секционная застройка, то есть застройка из небольших компактных помещений, перекрытых куполами или сводами; $\mathrm{g}$ - галерейная застройка, то есть вдоль стен проходят длинные коридорообразные помещения, перекрытые поперечными сводами; sg - секционно-галерейная 


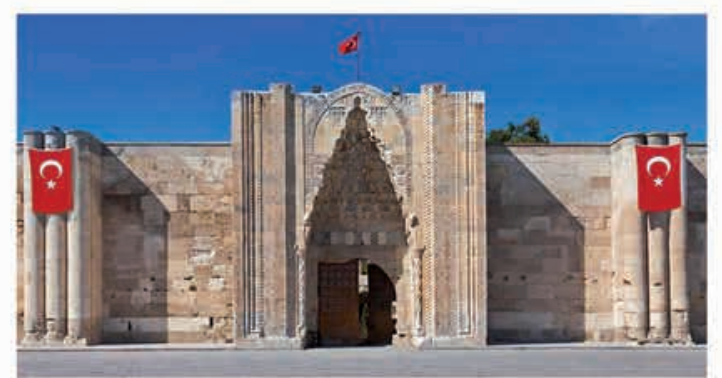

1

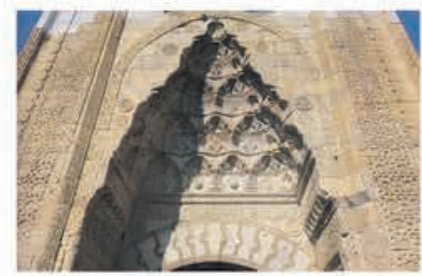

3

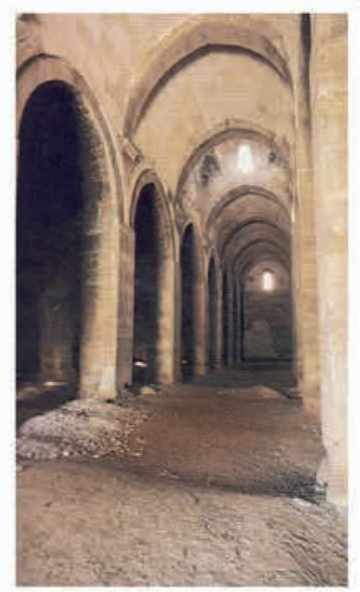

5

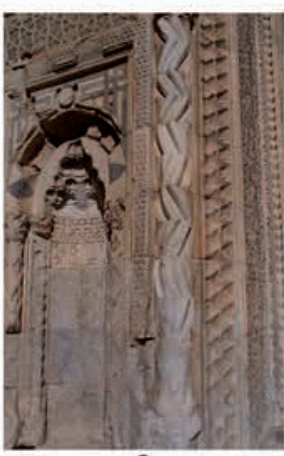

2

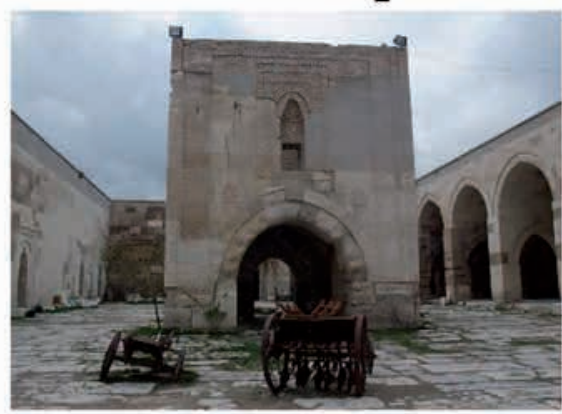

4

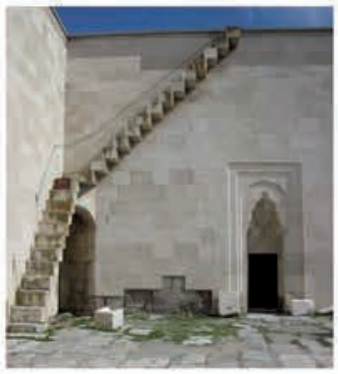

6

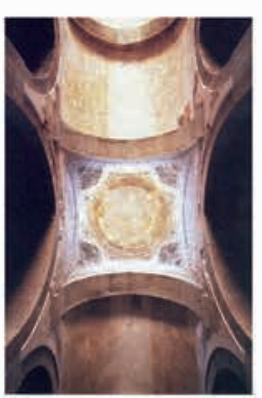

7

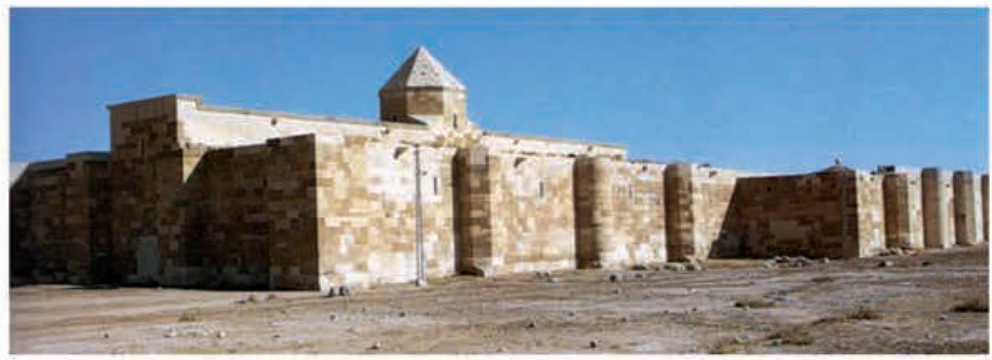

8

Рис. 12. Султан-хан, 1229 г. 1 - портал; 2-3-резной декор портала; 4 - внутренний двор с мечетью; 5-галереи; 6-лестница на крышу; 7 - подкупольное пространство; 8 - общий вид

Fig. 12. Sultan Khan, 1229. 1 - portal; 2-3-carved portal decoration; 4 - courtyard with a mosque; 5 -galleries; 6 - stairs to the roof; 7 -dome space; 8 -general view 
застройка. Чисто секционная или галерейная застройки встречаются редко, чаще всего двор застроен секциями в сочетании с галереями.

Помещения располагаются вдоль стен двора, причем не всегда вдоль всего периметра. Для дворовых караван-сараев характерна четырехайванная планировка, когда помещения, идущие вдоль четырех стен, расчленяются четырьмя большими лоджиями-айванами. Такая застройка на Среднем Востоке характерна для большинства категорий зданий, имеющих дворовую планировку (жилые постройки, мечети, медресе, ханака, караван-сараи). Истоки ее уходят корнями в глубокую древность и в настоящее время существуют различные точки зрения на происхождение четырехайванной композиции. В.В. Бартольд, Э. Херцфельд, а вслед за ними Б.А. Литвинский и Т.И. Зеймаль выводят эту планировку из буддийского зодчества, а именно из монастырей [Бартольд, 1927, с. 53-55; 1964, c. 30-31; Bartold, 1933, p. 29-31; Herzfeld, 1943, p. 13-30; Литвинский, Зеймаль, 2010, с. 108-112]. Другая точка зрения - это соотнесение всех зданий четырехайванной планировки с гражданской архитектурой, а именно с дворцовыми зданиями и жилыми домами. Сторонниками этой теории являются А. Годар, Г.А. Пугаченкова, С.Г. Хмельницкий, Р. Хилленбранд [Пугаченкова, 1958a, с. 341; Godard, 1962, p. 358-361; Хмельницкий, 1992, c. 204-206; Hillenbrand, 1994, p. 175].

Типы отражают расположение помещений: 2 - сплошная застройка вдоль двух стен; 3 - сплошная застройка вдоль трех стен; 4 - сплошная застройка вдоль четырех стен; 5 - четырехайванная планировка. При этом можно выделить подтипы по количеству рядов помещений вдоль стен: в один ряд - /1; в два ряда -/2; многорядная застройка: /1-2 или $12-3$.

И, наконец, важной деталью плана является колоннада вокруг двора, поддерживающая крытую галерею, то есть перистиль. Поэтому можно выделить вид двора с перистилем: Р - перистиль.

Например, однодворовый Ишан-рабат (рис. 3, 12) квадратный в плане, с одним входом и секционной застройкой вдоль двух стен в 1-2 ряда - I*AVs2/1-2. Однодворовый караван-сарай Суран (XI-XII вв.) имеет квадратный план сквозной проезд и секционно-галерейную застройку вдоль четырех стен в один ряд - I*AWsg4/1 (рис. 1, 2). Каравансарай Дая Хатын (X-XII вв.) - однодворовый, квадратный в плане с одним входом, галерейно-секционной планировкой (1 ряд), расчлененной четырьмя айванами и с колоннадой галереи вокруг двора - I*AVsg5/1P (рис. 2, 2). Дэу-кала (XI - началом XIII в.) - однодворовый, круглый в плане, с одним входом, секционной застройкой в 1-2 ряда, вдоль всего двора - I*CVs4/1-2 (рис. 8, 1).

Караван-сараи из подгруппы двухдворовых (I**) обычно прямоугольные в плане (В), но теоретически, могут быть и квадратными (А). У известных двухдворовых построек один вход, но не исключен и сквозной проход. В остальном, они делятся на те же порядки, типы и виды, с той лишь разницей, что нужно рассматривать каждый двор отдельно, так как застройка их может быть разной.

В настоящее время двухдворовых построек известно не много. Ахча-кала (XI-XII вв.) - прямоугольное в плане здание с одним входом и двумя дворами прямоугольной и квадратной формы (рис. 4, 1). Дворы 

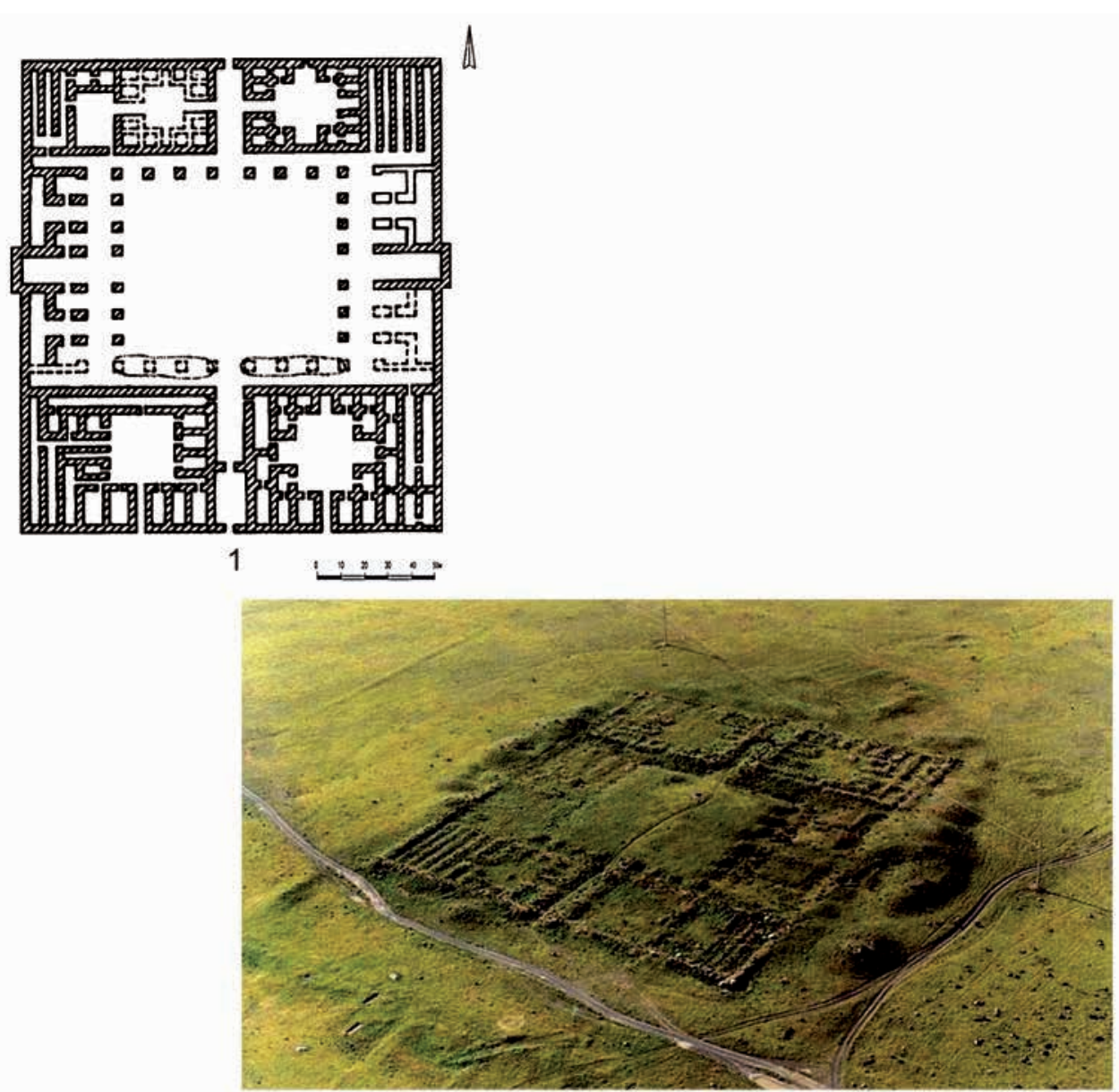

2

Рис. 13. Акырташ. 1 - план (по: [Хмельниикий, 1992]); 2 -аэрофото

Fig. 13. Akyrtash. 1 - plan (for: [Khmelnitsky, 1992]); 2 - aerial photo

его имеют сходное строение: они застроены секциями и галереями в 1-3 ряд, четырехайванные, с перистилем - I**BV Bsg5/1-2P+ Asg5/1-3P. Рабат-и Шараф (XI-XII вв.) также прямоугольный в плане с одним входом (рис. 4, 2). Первый двор его, вытянутый в широтном направлении, застроен секциями и галереями в 2 ряда, он четырехайванный с перистилем. Второй двор квадратных пропорций обстроен секциями в 1-2 ряда, он также четырехайванный с перистилем. В целом планировку можно представить символами: I**BV Bsg5/2 P+ Asg5/1-2P.
Многодворовые караван-сараи (I***) также могут быть квадратными (А) и прямоугольными (B) с одним входом (V) и сквозным проездом (W). Застройка секционногалерейная ( $\mathrm{sg})$, по периметру (4) или четырехайваннная (5) с перистилем (Р). Разница состоит в том, что вдоль стен расположены блоки помещений (B1), которые включают в себя внутренние дворики.

Примером такого здания является Акырташ - памятник, расположенный на юге Казахстана (рис. 13, 1-2). Стены его сложены из каменных блоков. Прямоугольное в плане 
здание имеет размеры $200 \times 180$ м и сквозной проезд. В центре, со сдвигом к западу, лежит прямоугольный двор с колоннадой по периметру. На осях двора, за галереей расположены четыре глубоких айвана, два из которых прорезаны входами. Углы постройки заняты четырьмя комплексами помещений, сгруппированных вокруг внутренних дворов. Восточные комплексы крупнее западных и имеют отдельные входы. В самом общем виде это здание можно представить как I***BWsg5B1P, но, несомненно, каждый блок помещений требует отдельного описания.

Существует еще один тип размещения помещений в многодворовых комплексах - Т-образный (Т). K этому типу относится описанный выше Рабат-и Малик (рис. 4). В первом периоде его квадратное в плане здание с одним входом состояло из большого переднего двоpa с застройкой вдоль одной стены и тремя дворами во второй части. В центре находился квадратный двор четырехайванной планировки и перистилем, а по бокам - два двора с застройкой вдоль двух стен. Условно тип здания можно представить следующим образом: I***AV sg1/1-3$+\mathrm{AVs} 5 / 1 \mathrm{P}+\mathrm{BVs} 2 / 1+\mathrm{BVs} 2 / 1 \mathrm{~T}$.

Во втором периоде передний двор разделяется дополнительными помещениями, а во втором, центральном, среднюю часть занимает закрытая галерея центрического плана: I***AV sg3/1-3+AVgZ+BVs2/1+ $\mathrm{BVs} 2 / 1 \mathrm{~T}$.

Следует признать, что в многодворовых зданиях сложного плана применение каких-либо кодов бесперспективно, так как архитектура их слишком индивидуальна и плохо поддается формализации.
II. Вторая группа представлена закрытыми, лишенными внутреннего двора, постройками. Здания этой группы также делятся на отделы: А - квадратные в плане и В - прямоугольные в плане. Вход у этих замкнутых построек обычно один (V). Квадратные в плане здания чаще всего разделены на небольшие комнаты, группирующиеся вокруг центрального помещения, то есть здесь присутствует секционная застройка (s) в сочетании с общей центрической планировкой (тип Z). Такую планировку имеют преобразованные в караван-сараи кешки. Ат-Тахмаладж (X-XI вв.) в Туркменистане (рис. 14, 1) представляет собой квадратное в плане здание, сырцовые стены которого покрывают гофры [Пугаченкова, 1958a, с. 166-167], вход в здание один. Внутри оно разделено на девять одинаковых квадратных помещений, которые соединяются между собой. Перекрыты они были куполами. Таким образом, план этого здания можно представить символами IIAVsZ. Сходную планировку имеет дорожная станция Зиндан-и Харун аль Рашид (X-XI вв.) недалеко от Рея [Hillenbrand, 1994, p. 334, 338, 410, 550; Kleiss, 1996, s. 115]. Это тоже квадратное в плане здание центрической планировки, но в середине его находится крестообразное помещение, центральная часть которого перекрыта куполом, а широкие боковые лоджии - сводами (рис. 14, 2). Куполами перекрыты и угловые квадратные комнаты. Несмотря на эти отличия, здание относится к тому же типу IIAVsZ. Квадратное здание станции в 21 км восточнее Сараба отличается тем, что центральный крестообразный зал с угловыми секциями окружают галереи (IIAVsgZ) [Kleiss, 1996, s. 49-50]. 

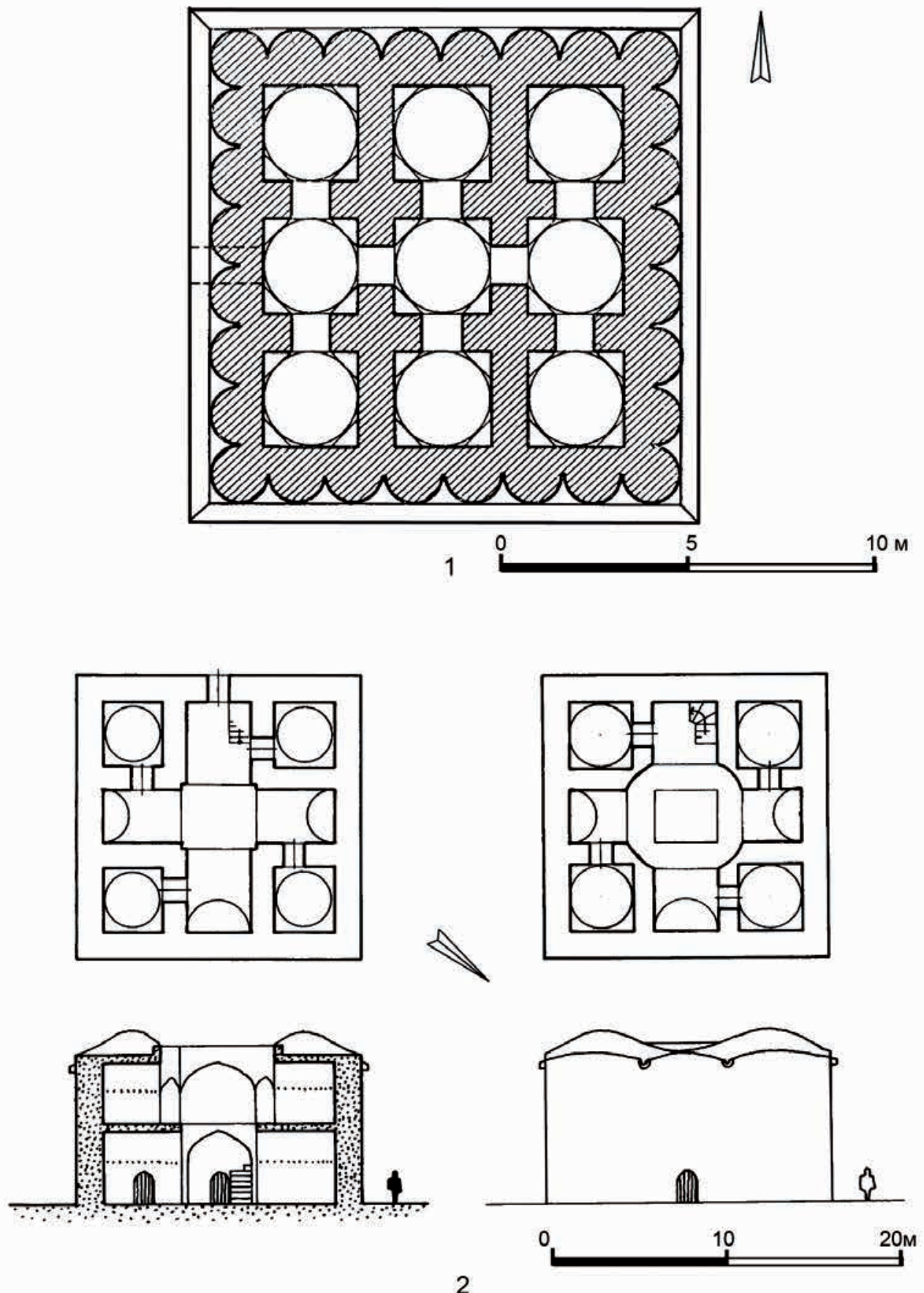

Рис. 14. Закрытые здания. 1 - Ат-Тахмаладж, Х-ХІ вв. (по: [Пугаченкова, 1958а]); 2 - Зиндан-и Харун аль Рашид, X-XI вв. (no: [Kleiss, 1996])

Fig. 14. Closed buildings. 1 -At-Tahmalaj, X-XI centuries (by: [Pugachenkova, 1958a]); 2 - Zindan and Harun al Rashid, X-XI centuries (by: [Kleiss, 1996]) 
Прямоугольные в плане (B) караван-сараи представляют собой сильно вытянутую галерею $(\mathrm{g})$. Типы можно выделить по количеству нефов галереи: однонефные (1), трехнефные (3), пятинефные (5). Как уже упоминалось, закрытые прямоугольные в плане постоялые дворы характерны для Армении. Например, караван-сарай Ахкенда (XII-XIII вв.) относится к типу IIBVg1 (рис. 9, 1), а Селима - IIBVg3 (рис. 9, 3). Некоторое количество таких построек средневекового времени известно в Иране. Там они укреплены угловыми башнями [Kleiss, 1996, s. 27, 78-80].

Третья группа (III) представляет собой синтез открытых и закрытых построек. В зданиях этого типа к дворовой части примыкает помещение без двора. В результате вся постройка имеет Т-образную форму (T). Вход в такие здания обычно один (V). Далее каждую из двух частей можно оценивать по тем же критериям, что и здания групп I и II. Так, каравансарай X в. Чаш-кала в Туркменистане (рис. 7,1 ) состоит из прямоугольного двора с одним входом и с секционной застройкой в один ряд по периметру и квадратного центрического здания, разделенного на небольшие комнаты - IIITV Bs4/1+AZs. Здание на городище Куртлы (XI в.) имеет почти такую же планировку, но его закрытая часть имеет второй выход на улицу, а застройка двора четырехайванная -IIITW Bs5/1+AZs (рис. 7, 2).

Большинство караван-сараев Малой Азии сельджукского периода состоят из двора с застройкой по периметру и длинного сводчатого помещения. Всемирно известный Султан-хан (рис. 11,11 ) состоит из прямоугольного двора, с двух сторон которого расположены комнаты, a с третьей - галереи и пятинефного вытянутого здания IIITW Bsg3/1-2$+\mathrm{Bg} 5$.

Предложенная классификация не может охватить абсолютно все здания данной категории, так как всегда встречаются постройки с нетипичной планировкой. Кроме того, некоторые детали архитектурного облика зданий (размеры и форма портала, наличие башен и контрфорсов, форма перекрытий, наличие водоемов и мечетей во дворе и т.д.) не вошли в нее. Тем не менее, мне кажется, что система достаточно универсальна и отражает большую часть элементов, из которых строится план здания. Индивидуальные же особенности памятников должны быть описаны отдельно. Кроме того, данная классификация позволяет изобразить планировку зданий в виде краткого кода.

\section{ЛИТЕРАТУРА}

1. Бартольд В.В. История культурной жизни Туркестана. Л.: Изд-во АН СССР, $1927.256 \mathrm{c}$.

2. Бартольд В.В. Туркестан в эпоху монгольского нашествия. Соч. в восьми томах. М.: «Наука», 1963. Т. 1.763 с.

3. Буряков Ю.Ф. По древним караванным путям Ташкентского оазиса. Ташкент: «Фан», 1978. 104 с.

4. Вишневская O.A. Раскопки караван-сараев Ак-яйла и Талайхан-ата // Археологические и этнографические работы Хорезмской экспедиции 1949-1953. Труды ХАЭЭ. М.: Изд-во АН СССР, 1958. Т. ІІ. С. 431-467. 
5. Всеобщая история архитектуры (ред. О.Х. Халпахчьян). Л.-М.: Изд-во литературы по строительству, 1970. Т. 1.512 с.

6. Всеобщая история архитектуры (ред. А.М. Прибыткова). Л.-М.: Изд-во литературы по строительству, 1969. Т. 8. 491 с.

7. Литвинский Б.А., Зеймаль Т.И. Буддийский монастырь Аджина-тепа. Раскопки. Архитектура. Искусство. СПб.: «Нестор-история», 2010. 320 с.

8. Маньковская Л.Ю. Типологические основы зодчества Средней Азии. IX начало ХХ в. Ташкент: «Фан», 1980. 184 с.

9. Маньковская Л.Ю. Формообразование и типология зодчества Средней Азии. IX - начало XX века. Ташкент: «Baktria Press», 2014. 496 с.

10. Мухамеджсанов А.Р., Адылов Ш.Т., Мирзахмедов Д.К., Семенов Г.Л. Городище Пайкенд. К проблеме изучения средневекового города Средней Азии. Ташкент: «Фан», 1988. 195 с.

11. Немцева Н.Б. Среднеазиатские караван-сараи в генетическом аспекте // Раннесредневековая культура Средней Азии и Казахстана (тез. всесоюзн. научн. конф в г. Пенджикенте). Душанбе, 1977. С. 163-165.

12. Немиева Н.Б. Рабат-и Малик // Художественная культура Средней Азии IX-XIII вв. Ташкент: Изд-во литер. и искусства, 1983. С. 135-146.

13. Немиева Н.Б. Рабат-и Малик: материалы раскопок // Отзвуки Великого Хорезма. К 100-летию со дня рождения С.П. Толстова. М., 2010. С. 267-311.

14. Пугаченкова Г.А. Пути развития архитектуры Южного Туркменистана поры рабовладения и феодализма. М.: Изд-во АН СССР, 1958а. 492 с.

15. Пугаченкова Г.А. Новые материалы к истории архитектуры Туркменистана. Труды ЮТАКЭ. Ашхабад, 1958б. Т. 8. 406 с.

16. Пугаченкова Г.А. Новое об архитектуре средневекового Мерва. Труды ЮТАКЭ. Ашхабад, 1963. Т. 12. 371 с.

17. Смирнова О.И. Очерки по истории Согда. М.: Наука, 1970. 288 с.

18. Толстов С.П. Древний Хорезм. М.: МГУ, 1948. 440 с.

19. Халпахчьян О.Х. Каравансараи Армении // АН. 1959. № 11. С. 105-133.

20. Халпахчьян O.X. Гражданское зодчество Армении (жилые и общественные здания). М.: Стройиздат, 1971. 245 с.

21. Хмельниикий C. Между арабами и тюрками. Архитектура Средней Азии IX-X вв. Берлин-Рига: «Continent», 1992. 344 с.

22. Хмельниикий C. Между Саманидами и монголами. Архитектура Средней Азии XI - начала XIII в. Берлин-Рига: «Gamajun», 1996. Ч. I. 336 с.

23. Barthold V. Der iranische Buddhismus und sein Verhältnis zum Islam // Oriental studies in honour of C.E. Pavry. London: Oxford University Press, 1933. P. 29-31.

24. Godard A. L'Art de Iran. Paris: Arthaud, 1962. 836 c.

25. Herzfeld E. Damaskus. Studies in Architecture. Ars Islamica.Vol. 10. Ann Arbor, 1943. P. 13-70.

26. Hillenbrand R. Islamic Architecture. New-York: Columbia University Press, 1994. $645 \mathrm{p}$.

27. Kleiss W. Karawanenbauten in Iran. T. I // Materialen zur Iranischen Archäologie, B. 2. DAI. Abteilung Teheran. Berlin, 1996. 322 p.

28. Stierlin H. Turkey from the Selçuks to the Ottomans. Köln: «Tachen», 1998. 238 p.

\section{Сведения об авторе:}

Зиливинская Эмма Давидовна - доктор исторических наук, ведущий научный сотрудник, Институт этнологии и антропологии им. Н.Н. Миклухо-Маклая РАН (Москва, Россия); eziliv@mail.ru 


\section{КЕРУЕН-САРАЙЛАР: \\ ГЕНЕЗИС, ӨЛКЕЛІК ЕРЕКШЕЛІКТЕРІ, ЖІКТЕЛУІ}

\section{Э.Д. Зиливинская}

Сауданың дамуына байланысты керуен жолдарының бойында жолаушылар тоқтайтын орындар пайда бола бастады, айта кететіні, олардың көнелері сонау б.д.д. II мыңжылдықтан белгілі. Шығыстағы араб жаулап алуларынан кейін «керуен-сарай» немесе «хан-сарай» деп аталған айтарлықтай стандарты және жақсы танымал жолаушылар тоқтайтын орындар қалыптасады. Орта Азия мен Иранда керуен-сарайлардың жоспарының негізіне ішінде әртүрлі үй-жайлар салынып, мықты қабырғалармен қоршалған кең аулалар жатады. Арменияда басқаларға ұқсамайтын жабық залды керуен-сарайлар қалыптасқан. Кіші Азияда керуен-сарайлардың аулалық және залдық ғимараттары өзара үндескен түрлері анағұрлым кеңінен таралған. Шығыс елдерінің керуен-сарайлары жинастырылған және жан-жақты талданған өте мол жалпыламалық жұмыстардың көптігіне қарамастан, осы уақытқа дейін ғимараттардың осы бір аса маңызды санатына арналған жіктеулер құрылмаған. Ұсынылып отырған жіктеулер құрылыстардың планиметриясына негізделген. Ұсынылатын жіктеулерге мынандай белгілер қолданылады: ашық ауланың бары мен жоғы, қора саны, жоспарының түрі, кірер есік саны, ауланың құрылысы, үй-жайлардың орналасуы, ұсынтізбектің баржоғы. Ұсынылып отырған жіктеу анағұрлым әмбебап және ғимараттың жоспарын құрайтын бөлшектердің басым бөлігін қамтиды. Сонымен қатар, ол ғимараттың жоспарын қысқа кілт арқылы суреттеуге мүмкіндік береді.

Түйін сөздер: археология, Орта Азия, Армения, Кіші Азия, Иран, Ұлы Жібек жолы, ортағасырлар, сауда, керуен-сарайлар, генезис, жіктеу

\section{CARAVANSERAIS: \\ GENESIS, REGIONAL FEATURES, CLASSIFICATION}

\section{E.D. Zilivinskaya}

With the development of trade on the caravan routes, inns appear, the earliest known already in the 2nd millennium BC. After the Arab conquests in the East, a fairly standard and well-known inn type, called "caravanserai" or "han ". In Central Asia and Iran, at the heart of the caravanserai plan is a vast courtyard surrounded by powerful walls, to which various premises are attached from within. In Armenia, an original type of closed caravanserai hall was developed. The most common type of caravanserai in Asia Minor is a synthesis of courtyard and hall buildings. Despite the fact that there are quite a few generalizing works in which caravanserais of various countries of the East are collected and analyzed, a classification of this very important category of buildings has not yet been created. The proposed typology is based on the planimetry of buildings. The proposed classification uses the following characteristics: the presence or absence of an open courtyard, the number of courtyards, the shape of the plan, the number of entrances, the building of the courtyard, the location of the rooms, the presence of a colonnade. The proposed classification is quite universal and reflects most of the elements that make up the floor plan. In addition, it allows you to depict the layout of buildings in the form of a short code.

Keywords: archaeology, Central Asia, Armenia, Asia Minor, Iran, Great Silk Road, Middle Ages, trade, caravanserai, genesis, classification 


\section{REFERENCES}

1. Bartold, V. V. 1927. Istoria kulturnoi zhizni Turkestana (The history of the cultural life of Turkestan). Leningrad: AN SSSR Publ. (in Russian).

2. Bartold, V. V. 1963. Turkestan v epohu mongolskogo nashestvia (Turkestan in the era of the Mongol invasion ). Moscow: «Nauka» Publ. (in Russian).

3. Buryakov, Ju. F. 1978. Po drevnim karavannym putjam Tashkentskogo oazisa (On the ancient caravan routes of the Tashkent oasis). Tashkent: „Fan“ Publ. (in Russian).

4. Vishnevskaya, O. A. 1958. In Arheologicheskie $i$ etnograficheskie raboty Horezmskoi ekspeditsii 1949-1953. Trudy HAEE. T. II (Archaeological and ethnographic works of the Khorezm Expedition 1949-1953. Proceedings of HAEE. T. II). M.: AN SSSR Publ., 431-467 (in Russian).

5. Vseobschaja istorija arhitektury (General History of Architecture), 1. 1970. Leningrad-Moscow: Izd-vo literatury po stroitelstvu (in Russian).

6. Vseobschaja istorija arhitektury (General History of Architecture), 8. 1969. Leningrad-Moscow: Izd-vo literatury po stroitelstvu (in Russian).

7. Litvinskii, B. A., Zeimal, T. I. 2010. Buddiiskii monastyr Adzhina-tepa. Raskopki. Arhitektura. Iskusstvo (Buddhist monastery Ajina Tepa. Excavations. Architecture. Art). Saint Petersburg: «Nestor-istoria» Publ. (in Russian).

8. Mankovskaya, L. Ju. 1980. Tipologicheskie osnovy zodchestva Srednej Azii. IX - nachalo XX v. (Typological foundations of Central Asian architecture. IX-early XX century). Tashkent: «Fan» Publ. (in Russian).

9. Mankovskaya, L. Ju. 2014. Formoobrazovanie i tipologija zodchestva Srednej Azii. IX-nachalo XX veka (The formation and typology of the architecture of Central Asia. $I X$ - early XX century). Tashkent: «Baktria Press» Publ. (in Russian).

10. Muhamejanov, A. R., Adylov, Sh. T., Mirzahmedov, D. K., Semenov, G. L. 1988. Gorodische Pajkend. K probleme izuchenija srednevekovogo goroda Srednei Azii (Pikend site To the problem of studying the medieval city of Central Asia). Tashkent: «Fan» Publ. (in Russian).

11. Nemtseva, N. B. 1977. In Rannesrednevekovaya kultura Srednei Azii i Kazahstana (Early medieval culture of Central Asia and Kazakhstan ). Dushanbe, 163-165 (in Russian).

12. Nemtseva, N. B. 1983. In Hudozhestvennaya kultura Srednei Azii IX-XIII vv. (Artistic culture of Central Asia IX-XIII centuries.) Tashkent: Izd-vo liter. i iskusstva, 135146 (in Russian).

13. Nemtseva, N. B. 2010. In Otzvuki Velikogo Horezma (Echoes of the Great Khorezm). Moscow, 267-311.

14. Pugachenkova, G. A. 1958a. Puti razvitija arhitektury Juzhnogo Turkmenistana pory rabovladenija i feodalizma (Ways of developing the architecture of Southern Turkmenistan pores of slavery and feudalism). Moscow: AN SSSR Publ. (in Russian).

15. Pugachenkova, G. A. 1958b. In Trudy JuTAKE (Proceedings of YTAKE), 8. Ashhabad (in Russian).

16. Pugachenkova, G. A. 1963. In Trudy JuTAKE (Proceedings of YTAKE), 12. Ashhabad (in Russian).

17. Smirnova, O. I. 1970. Ocherki po istorii Sogda (Essays on the history of Sogd). Moscow (in Russian).

18. Tolstov, S. P. 1948. Drevnii Horezm (Ancient Khorezm). M.: Moscow State University Publ. (in Russian).

19. Halpahchyan, O. H. 1959. In Arhitekturnoe nasledstvo (Architectural heritage), 11, 105-133 (in Russian). 
20. Halpahchyan, O. H. 1971. Grazhdanskoe zodchestvo Armenii (zhilye i obschestvennye zdanija) (Armenian civil architecture (residential and public buildings)). Moscow: Stroiizdat (in Russian).

21. Hmelnitskii, S. 1992. Mezhdu arabami i tjurkami. Arhitektura Srednej Azii IX-X vv. (Between the Arabs and the Turks. Architecture of Central Asia IX-X centuries). Berlin-Riga: «Continent» (in Russian).

22. Hmelnitskii, S. 1996. Mezhdu Samanidami i mongolami. Arhitektura Srednej Azii XI - nachala XIII vv. (Between the Samanids and the Mongols. The architecture of Central Asia XI - early XIII centuries). Berlin-Riga: "Gamajun" Part I (in Russian).

23. Barthold, V. 1933. Der iranische Buddhismus und sein Verhältnis zum Islam // Oriental studies in honour of C.E. Pavry. London, Godard A. L'Art de Iran. Paris, 836 p.

24. Godard A. L'Art de Iran. Paris: Arthaud, 1962.836 c.

25. Herzfeld E. 1943. Damaskus. Studies in Architecture. Ars Islamica. Vol. 10. Ann Arbor, 13-70.

26. Hillenbrand R. 1994. Islamic Architecture. New-York, 645 p.

27. Kleiss W. 1996. Karawanenbauten in Iran. T. I // Materialen zur Iranischen Archäologie, B. 2. Deutsches Archäologisches Institut. Abteilung Teheran. Berlin, 322 p.

28. Stierlin H. 1998. Turkey from the Selçuks to the Ottomans. Köln: Taschen, 238 p.

\section{About the Author:}

Zilivinskaya Emma D. Doctor of Historical Sciences, leading researcher, N.N. Miklukho-Maklay Institute of Ethnology and Anthropology RAS, Moscow, Russia; eziliv@mail.ru

Мүдделер қақтығысы туралы ақпаратты ашу. Автор мүдделер қақтығысының жоқтығын мәлімдейді. / Раскрытие информации о конфликте интересов. Автор заявляет об отсутствии конфликта интересов. / Disclosure of conflict of interest information. The author claim no conflict of interest.

Мақала туралы ақпарат / Информация о статье / Information about the article. Редакцияға түсті / Поступила в редакцию / Entered the editorial office: 27.02.2019.

Рецензенттер мақұлдаған / Одобрено рецензентами / Approved by reviewers: 06.03.2019. Жариялауға қабылданды / Принята к публикации / Accepted for publication: 13.03.2019. 